\title{
New nanomaterials for applications in conservation and restoration of stony materials: A review
}

\author{
A. Sierra-Fernandez ${ }^{\mathrm{a}, \mathrm{b}}$, L.S. Gomez-Villalba ${ }^{\mathrm{a}}$, M.E. Rabanal ${ }^{\mathrm{b}, \mathrm{c}}$, R. Fort ${ }^{\mathrm{a}} \bowtie$ \\ a. Instituto de Geociencias, CSIC, UCM. (Madrid, Spain) \\ b. Department of Materials Science and Engineering and Chemical Engineering. Carlos III University of Madrid (Madrid, Spain) \\ c. Instituto Tecnológico de Química y Materiales Alvaro Alonso Barba (IAAB-UC3M), (Madrid, Spain) \\ $\triangle$ rafael.fort@csic.es
}

\author{
Received 23 June 2016 \\ Accepted 22 July 2016 \\ Available on line 20 January 2017
}

\begin{abstract}
In recent times, nanomaterials have been applied in the construction and maintenance of the world's cultural heritage with the aim of improving the consolidation and protection treatments of damaged stone. These nanomaterials include important advantages that could solve many problems found in the traditional interventions. The present paper aims to carry out a review of the state of art on the application of nanotechnology to the conservation and restoration of the stony cultural heritage. We highlight the different types of nanoparticles currently used to produce conservation treatments with enhanced material properties and novel functionalities.
\end{abstract}

KEYWORDS: Nanotechnology; Cultural heritage; Stone; Mortar; Durability

Citation/Citar como: Sierra-Fernández, A.; Gómez-Villalba, L.S.; Rabanal, M.E.; Fort, R. (2017) New nanomaterials for applications in conservation and restoration of stony materials: A review. Mater. Construcc. 67 [325], e107. http:// dx.doi.org/10.3989/mc.2017.07616

RESUMEN: Revisión de los nuevos nanomateriales para la conservación y restauración del material pétreo. En los últimos tiempos la aplicación de las nanopartículas en el campo de la conservación del patrimonio pétreo construido está siendo llevada a cabo con el fin de obtener tratamientos mejorados de consolidación y protección. Estos productos incorporan importantes ventajas que pueden solucionar muchos de los problemas encontrados en las intervenciones tradicionales de conservación del patrimonio. De este modo, el presente trabajo de investigación toma como objetivo la revisión sobre la aplicación de la nanotecnología a la conservación y restauración del patrimonio pétreo. Se destacan los diferentes tipos de nanopartículas más comúnmente utilizados hoy en día para llevar a cabo tratamientos de conservación con propiedades mejoradas y nuevas funcionalidades.

PALABRAS CLAVE: Nanotecnología; Patrimonio cultural; Piedra; Mortero; Durabilidad

ORCID ID: A. Sierra-Fernandez (http://orcid.org/0000-0002-7874-4742); L.S. Gomez-Villalba (http://orcid.org/00000002-8755-8191); M.E. Rabanal(http://orcid.org/0000-0002-5090-6498); R. Fort(http://orcid.org/0000-0001-9967-2824)

Copyright: (C) 2017 CSIC. This is an open-access article distributed under the terms of the Creative Commons Attribution License (CC BY) Spain 3.0.

\section{INTRODUCTION}

The basic principle of the patrimony is that the cultural heritage is an incalculable and integral legacy to our future. The obligation to preserve and provide access to it is an absolute necessity. Nowadays, it warns a growing concern for the situation that the degradation of this rich and fragile heritage has reached. In addition, conservation of stone heritage is always a delicate and complex challenge. Multiple variables have to be taken into account to identify the problems, define the necessary conservation actions and to select materials and procedures to be used. The variety of factors to be analyzed includes 
the intrinsic stone properties, the state of conservation, the degradation mechanisms and the environmental factors. Thus, it is necessary to select the appropriate materials and procedures for a correct conservation treatment. Compatibility, depth of penetration, durability, effect on liquid water and vapor permeability, in addition to biological resistance, application method, or health matters are important factors to take into account.

While the development in material science has generated important nanostructured materials long time ago, conservation of cultural heritage was, until recently, mainly based on the traditional conservation and restoration treatments. These traditional methods, such as the use of synthetic polymers, often lack the vital compatibility with the original substrate and a durable performance. More recently, nanomaterials are being applied in the construction and maintenance of the architectural heritage with the aim of improving the consolidation and protection treatments of damaged building materials. Firstly, Baglioni and co-workers were pioneering in the application of nanoparticles for the cleaning and consolidation of mural paintings (1). Later, the application of nanoparticles to stone heritage started through works of Dei and Salvadori (2) and Manoudis et al. (3). Subsequently, the nanoparticles specifically designed for cleaning, consolidation, water repellence, as well as for antimicrobial and anti-graffiti treatments have been developed.

Consolidation is one of the most important conservation treatments carried out on stone heritage. This treatment is used to improve the cohesion of weathered stone when serious decay patterns and indepth cohesion loss are present. Consolidation treatments are the most risky conservation actions due to their irreversibility and the likeliness to cause undesired effects, such as the possible loss of the surface that was supposed to be preserved. This risk justifies the numerous studies that have been developed on stone consolidants. The application of nanotechnology in the cultural heritage conservation is marked by the possibility to design consolidant products highly compatible with the original stone substrate. Moreover, when particles have dimensions of about 1-100 nanometers, the materials properties change significantly from those at larger scales. In this sense, nanomaterials have larger surface areas than similar masses of larger-scale materials, which increase their chemical reactivity. In addition, these nanomaterials present the possibility to penetrate deep into the damaged stone materials due to the particle size.

On the other hand, atmospheric pollution is dramatically increasing the external degradation of monuments and buildings due to the deposition of organic matter and other contaminants on the stone substrates (Figure 1). In this context, one of the main particularities on the use of nanoparticles is its photocatalytic capacity, which prevents the excessive
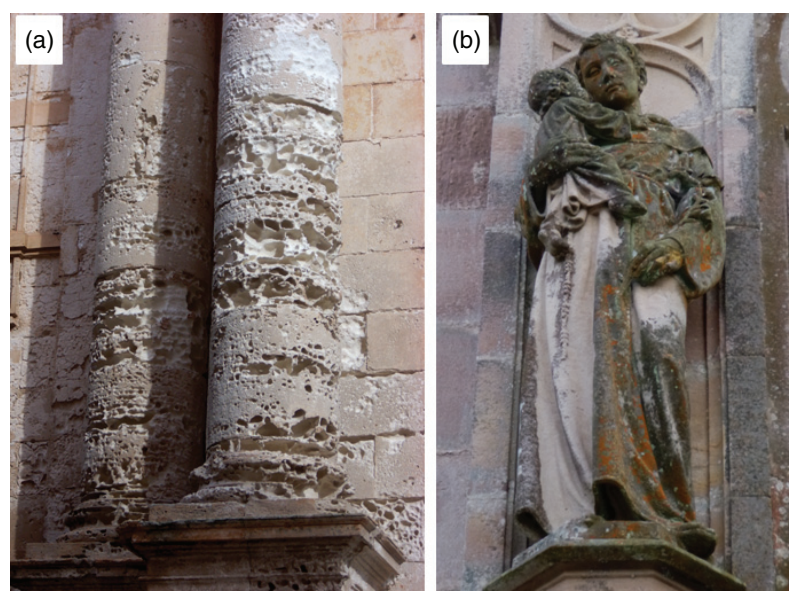

FIGURE 1. Degraded stone heritage showing: a) salt weathering of building stone, and b) visible microbial growth and staining.

contamination and the growth of microorganisms on the building facades allowing an easier removal of biological stains, soiling and biofouling from surfaces $(4,5)$. In this way, innovative applications have reached by using nanoparticles in building materials such as environmental pollution remediation and self-cleaning and anti-microbial effect.

Since ancient times, these properties are known in different elements (Ag, Ti, Cd, Fe, Pd, Zn, Pt, $\mathrm{Co}$, etc). The nanoparticles must have the following attributes: stability and sustained photoactivity, biologically and chemically inert, nontoxic, low cost, suitability towards visible or near UV light, high conversion efficiency and high quantum yield, could be react with wide range of substrate and high adaptability to various environment and good adsorption in solar spectrum (6). In addition, these treatments can also have water repellent properties which favor this self-cleaning action $(7,8)$, and prevent the generation of damage caused by water. The nanostructured particles can provide not only hydrophobic and repellence properties to the stone substrate but also superhydrophobic properties (9), which generate water contact angle greater than $150^{\circ}$.

The nanoparticles can also be used as additives in construction materials or to modify the synthetic polymers in order to enhance its outdoor performance, and its mechanical and thermal properties $(10,11)$. Moreover, capsules with high initial flexibility are even used for self-healing concretes (12). On the other hand, the presence of soluble salts is recognized as an important decay agent of stone heritage. Thus, in the last few years, the study of the application of nanoparticles as a de-sulphating agent for stone, mortars and wall paintings are being carried out (13).

An important aspect in order to establish the suitability and the effectiveness of the treatments based 
on nanoparticles is to take into account the synthesis method used for obtaining the nanoparticles. The influence of experimental synthesis parameters that can modify the morphologies, particle sizes, agglomeration level and crystalline structures of the nanoparticles obtained has to be analyzed.

This review focuses on the current state of knowledge in the application of different types of nanoparticles for the improvement of conservation strategies of the cultural built heritage.

\section{CONSOLIDANT PRODUCTS}

\subsection{Inorganic nanomaterials}

\subsubsection{Consolidants based on $\mathrm{Ca}(\mathrm{OH})_{2}$ nanoparticles applied in rocks (limestones, dolostones), and mortars}

One of the most commonly used inorganic consolidants are the products based on hydroxide nanoparticles due to its compatibility with a large part of the built and sculptural heritage. Calcium hydroxide (also known as lime wash putty) is one of the oldest products used in construction, mainly as a binder in mortars (joint mortars, renderings, wall fillings, etc), in mural paintings, as a consolidant product, together with other materials such as rammed-earth.

It can be used to restore the cohesion loss by filling the porosity of calcareous stones (limestones, marbles, and mortars). When calcium hydroxide is exposed to atmospheric $\mathrm{CO}_{2}$ in wet conditions, the layered network of its hexagonal packing crystal structure favors the incorporation of such $\mathrm{CO}_{2}$ to the structure producing the carbonation process, which consists of reacting and transforming into calcium carbonate (Figure 2). However, this approach has resulted in many cases unsatisfactory by the poor penetration of the dissolution inside the stone material and its inability to achieve complete consolidation of the damaged area of the material. New products based on nanoparticles can modify its properties and be used in protection and consolidation of geomaterials including marbles, dolostones, limestones (14), mortars. Significant progress has been achieved using colloidal nanoparticles calcium hydroxide-based, commercially distributed among which the most used are Nanorestore (2), Calosil (15) for obtaining calcium carbonate, which acts on the carbonate rock modifying the pore structure. However, it is important to assess whether their characteristics are compatible or not with petrological aspects and mineralogical or local environmental conditions they are exposed and amend the process and therefore its effectiveness (16). Like all products used in treatments of consolidation, consolidating products based on nanoparticles, different agents are susceptible to extrinsic and intrinsic factors that influence its stability and can, at a given time, alter their specific properties, such as relative humidity (17), exposure time (18), temperature changes (19) or its stability with over time (20). Differences in the carbonation process in nanoparticles are associated with several factors among which are the presence of $\mathrm{CO}_{2}$ in the environment and the presence of water (liquid or vapour phase) (21) as an accelerator of the process, producing differences in the nucleation and growth of different calcium carbonate polymorphs (22). This behaviour affects the reactivity of minerals, their crystallinity and the porosity and petrophysical properties of the stone surface to which nano lime has been applied $(23,18)$.

Progress in the use of consolidating products based on calcium hydroxide nanoparticles for the consolidation of carbonate stone materials has been increasing in the last years. One of the main

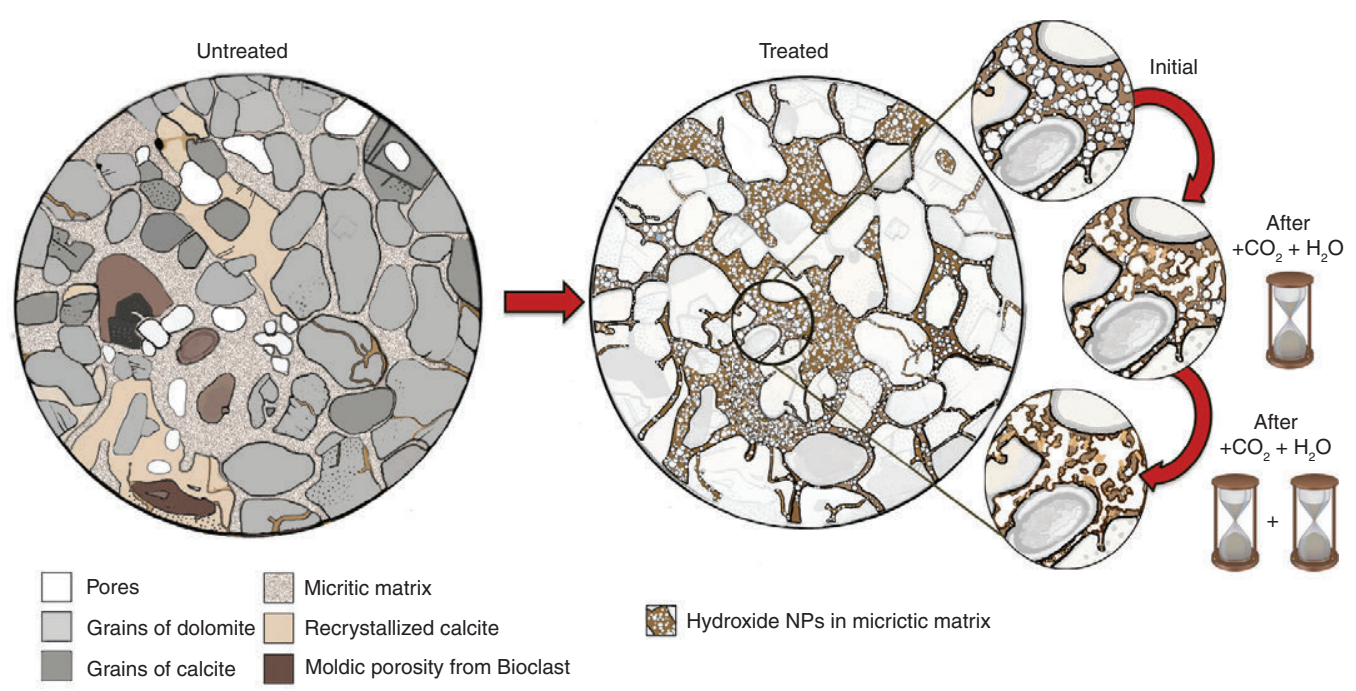

FIgURE 2. A schematic illustration of the thin film of dolostone before and after treatment with hydroxide nanoparticles. 
objectives has been to improve its properties to ensure the success of the process, including control of morphology and size of the nanoparticles (24), rate and the effect of carbonation in crystal growth (25), degree of crystallinity, penetration depth, concentration of solution (23), additives, catalysers (26) or solvents, and solubility (27).

One of the main factors that have been proven to be the clue to produce the carbonation has been the effect of the relative humidity. Carbonatation reaction produces different polymorphs of calcium carbonate, which have different stability and morphology. When it comes to be applied in the stony substrate, the behavior is different depending on the relative humidity. Therefore, in dry environments is slower giving rise to low crystallinity calcium carbonate (28). However, it is not the same in wet environments where carbonation is faster; however it not only produces calcite, the most stable of all polymorphs, but mainly acicular aragonite or unstable polymorphs as vaterite and even hydrated phases of ikaite or monohydrocalcite that can affect to the substrate in the same way as it would do other salt contributing to the loss of cohesion (22).

Due to the influence of relative humidity on carbonation, not always achieved to form calcite, as it is the case of nanoparticles that are exposed to very low humidity relative $(33 \%)$ and which still conserve calcium hydroxide although they have been exposed for a long period of time $(28,29)$.

In order to accelerate the carbonation process, nowadays are being tested different routines, which include the use simple accelerators as yeast, which contributes to accelerate the carbonation in calcium hydroxide nanoparticles (26).

The results of treatment with $\mathrm{Ca}(\mathrm{OH})_{2}$ nanoparticles from commercial products obtained by colloidal synthesis $\left(\right.$ Calosil $\left.^{\mathbb{R}}\right)$ applied on dolomite stones from Redueña (Spain) with different concentrations have demonstrated the development of surface with carbonatic efflorescences, which has been observed in samples treated with the product in high concentration (15 and $25 \%$ ) and heterogeneous porosity. Changes in the color and brightness, for instance, are reason enough to discourage the application of this treatment in high concentrations on this type of porous dolostones (23).
However, when the same product $\left(\mathrm{Calosil}^{\circledR}\right)$ is applied in low concentration $(1.5 \mathrm{~g} / \mathrm{l})$ can result in a natural method, compatible with the petrological characteristics of the substrate, without secondary damages on the stone, being an effective method to improve the durability of carbonate stones (30).

It is essential to conduct a previous study of mineralogical and chemical compatibility between consolidating product/stone to avoid developing unaesthetic neomineralizations in the stone. Therefore a mineralogical and textural control can early diagnose possible pathologies developed as a result of no suitable treatments (Figure 3) (23).

Although portlandite (Nanorestore ${ }^{\circledR}$ ) has been applied to dolostones and calcitic dolostones getting an improvement in their hydric and physical properties more effectively in wet than in dry environments, without changes in color, their effect has produced phenomena of dolomite dissolution and calcite recrystallization (18). This behavior is expected being its application more suitable to be applied in limestone.

These nanomaterials include significant advantages that could solve many problems found in the traditional interventions of the stone consolidation. However, the physical-chemical compatibility of these consolidants with the stone material is one of the most important requirements for its use in heritage preservation. Therefore, the new goal consists in the development of new consolidant products based on $\mathrm{Mg}(\mathrm{OH})_{2}$ nanoparticles in order to preserve the dolostone used in built heritage (31).

In the field of the mortars, the commercial

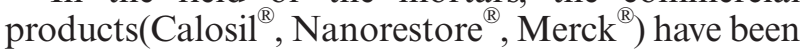
tested on dry hydrated lime and fine crushed calcareous aggregate (32); powdered lime hydrate and river sand (33) and siliceous and lime mortars (34). The effectiveness depends on the type of mortar and humidity conditions to which they are exposed.

\subsubsection{Consolidant products based on $\mathrm{Mg}(\mathrm{OH})_{2}$ nanoparticles}

Dolostone represents one of the materials most used in the history of construction in the world. The damage experienced by these materials generates a

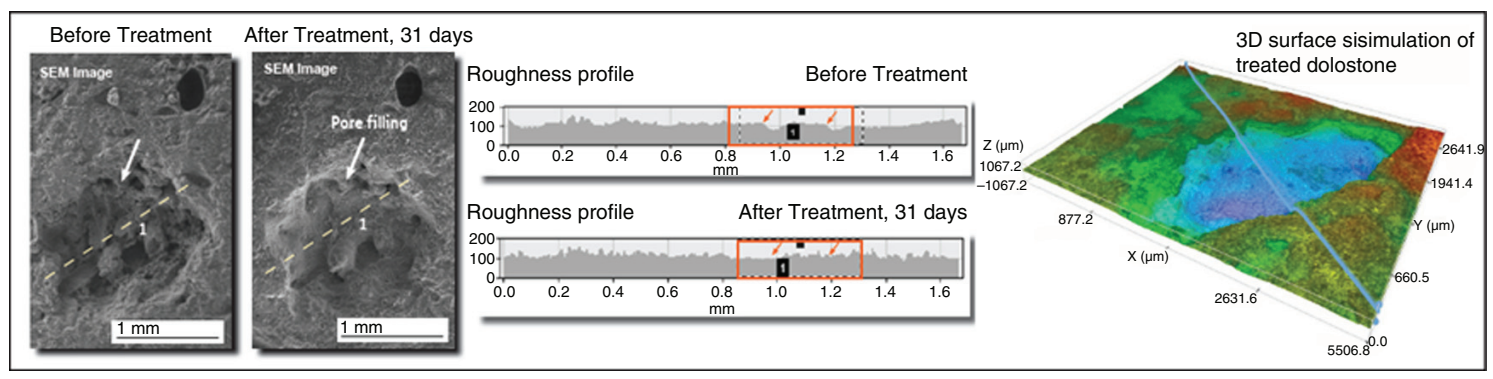

FIGURE 3. ESEM Images and roughness profiles obtained of treated and untreated Laspra dolostone (Spain). 
significant loss of internal cohesion that makes the application of consolidant products necessary. As mentioned, consolidant products based on calcium hydroxide nanoparticles are one of the most commonly used nanomaterials in stone consolidation. To our knowledge, it is important to take into account that in dolomite crystals, layers of carbonate ions alternate with layers of magnesium and calcium ions (35). Variables such as the possible $\mathrm{Mg}^{2+} / \mathrm{Ca}^{2+}$ ion exchange in the stone-consolidant system, the influence of particle size on carbonation kinetics or the surface tension differences in the medium, have to be taken into account. In this way, the application of calcium hydroxide nanoparticles in dolostone could generate nano-calcite recrystallized, leading the dolomite dissolution due to the calcium ion enrichment (18). This is why the effectiveness of the use of calcium hydroxide nanoparticles is reduced in dolostone substrate.

The dedolomitization is another risk arising as a result of the use of calcium hydroxide nanoparticles for the dolostone consolidation. In alkaline conditions, the dolomite can react with alkali hydroxides causing a fine intergrowth of brucite, calcite and alkali carbonates. This process would regenerate alkalis and thereby permit a continued reaction with the dolomite (36). In addition, the expansion and the cracking of dolostone substrates occur when the dedolomitization happens (36-38). Works carried out by Berube et al. (39) showed that extensive dedolomitization occurred when dolomite was immersed in a lime solution. Thus, one of the main goals consists in the development of new consolidant products based on $\mathrm{Mg}(\mathrm{OH})_{2}$ (brucite) nanoparticles, with morphology, crystalline structures, and compatibility suitable for application in the dolostone used in built heritage (30). The consolidant action of this type of nanoparticles is based on their carbonation reaction in the presence of $\mathrm{CO}_{2}$ and relative humidity, which result is the precipitation of magnesium carbonate $\left(\mathrm{Mg}\left(\mathrm{CO}_{3}\right)\right.$ (Figure 4). The consolidation of dolostone can be achieved through the application of a mixed $\mathrm{Ca}(\mathrm{OH})_{2}$ and $\mathrm{Mg}(\mathrm{OH})_{2}$ nanoparticles dispersions. In order to obtain a durable consolidation, mixed calcium and magnesium hydroxides, obtained by thermomechanical treatment of lime and via homogeneous phase reaction, respectively, have been applied in a high porosity dolostone (40).

\subsection{3. $\mathrm{Ba}(\mathrm{OH})_{2}$ nanoparticles as consolidant product}

Barium hydroxide $\left(\mathrm{Ba}(\mathrm{OH})_{2}\right)$ has been widely used as a consolidant product for carbonate stones during decades and represents a potential alternative to calcium hydroxide given its greater solubility in water $(41,42)$. Literature suggests that when barium ions are in contact with calcium carbonate crystals, along with carbonation, a significant degree of exchange of barium ions for calcium ions is achieved. Therefore, the precipitated barium carbonate is directly bonded to the surface of calcium carbonate crystals and thus, the new mineral phase increases its adherence to the stone material $(41,43)$. In this way, the consolidant action of the barium hydroxide is based on its carbonation reaction with the carbon dioxide, which results in the formation of barium carbonate $\left(\mathrm{BaCO}_{3}\right)$. However, one of the most important disadvantages of using $\mathrm{Ba}(\mathrm{OH})_{2}$ as a consolidant product is its low penetration capacity into the stone material (44). Several techniques have been proposed in order to introduce the $\mathrm{Ba}(\mathrm{OH})_{2}$ into the stone matrix. Lewin (45) promoted the carbonation of the barium hydroxide more effectively by adding urea to the solution due to the fact that the urea produces a slow and controlled precipitation of barium carbonate from the barium hydroxide solution. However, Schnabel (46) evaluated the $\mathrm{Ba}(\mathrm{OH})_{2}$-urea method applied to marble and porous limestones and suggested that the effectiveness of the method is reduced when it is applied by capillarity in situ. In this context, the use of controlled nano-sized barium hydroxide particles allows an increased penetration depth of the nanoparticles into the stone matrix, due to the small average size of the particles $(47,48)$. Furthermore, barium hydroxide solutions have been widely applied to the consolidation of gypsum materials and wall-paintings through a procedure known as the Ferroni-Dini

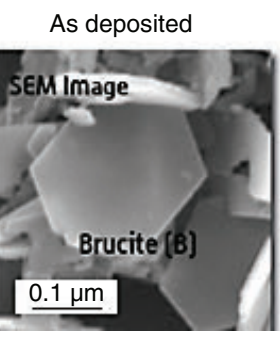

$\mathrm{Mg}(\mathrm{OH})_{2}$

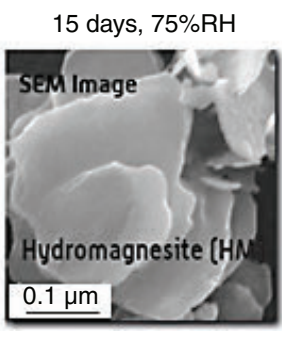

$\left(\mathrm{Mg}_{5}\left(\mathrm{CO}_{3}\right)_{4}(\mathrm{OH})_{2}-4 \mathrm{H}_{2} \mathrm{O}\right)$

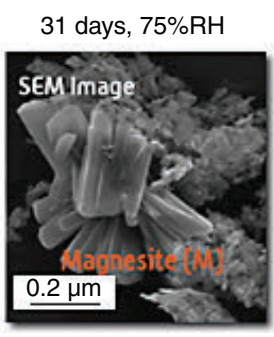

$\left(\mathrm{MgCO}_{3}\right)$

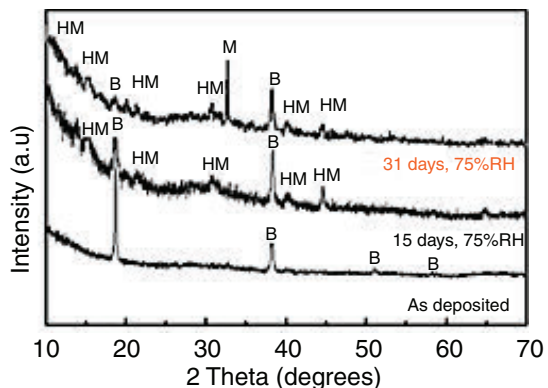

FIGURE 4. SEM images and XRD patterns of magnesium hydroxide nanoparticles obtained by hydrothermal method, before and after 15 and 31 days at $75 \% \mathrm{RH}$. 
method or Florentine method (49). The gypsum can be converted into barium sulfate when using the first step of the Ferroni-Dini method (treatment with ammonium carbonate). Later, the application of barium hydroxide solution allows the stone consolidation. Baglioni et al. (48) suggest the use of mixed formulations of $\mathrm{Ca}(\mathrm{OH})_{2}$ and $\mathrm{Ba}(\mathrm{OH})_{2}$ nanoparticle dispersions for the pre-consolidation of surfaces extremely affected by sulfates, after the application of the first part of the Ferroni-Dini method.

On the other hand, barium hydroxide has also been applied as additive material in conservation mortars. Thus, the effect of barium hydroxide on the setting mechanism of lime-based mortars has been studied by Karatasios et al. (41). Their results suggested that $\mathrm{Ba}(\mathrm{OH})_{2}$ produced a homogeneous binding material, consisting of calcite $\left(\mathrm{CaCO}_{3}\right)$, witherite $\left(\mathrm{BaCO}_{3}\right)$ and barium-calcium carbonate $\left(\mathrm{BaCa}\left(\mathrm{CO}_{3}\right)_{2}\right)$, without causing any defects. They also found the carbonation of barium hydroxide much faster than that of calcium carbonate. Moreover, barium hydroxide was found to have a positive effect on the sulphate-resistance of limebased mortars by blocking $\mathrm{Ca}^{2+}$ dissolution, when used as an additive material to the lime binder (50). In this way, the formation of barium phases within the mass of lime binder could increase the durability of conservation mortars.

The effectiveness of barium hydroxide as an additional activator in alkali $\mathrm{Ca}(\mathrm{OH})_{2}$-activated ground granulated blast-furnace slag (GGBS) mortars mixed and cured at air-dried and water conditions has also been reported (51). These researchers determined that the addition of $\mathrm{Ba}(\mathrm{OH})_{2}$ could led the development of alkali-activated mortars with a higher strength due to the formation of $2 \mathrm{CaO} \cdot \mathrm{Al}_{2} \mathrm{O}_{3} \cdot \mathrm{SiO}_{2} \cdot 8 \mathrm{H}_{2} \mathrm{O}$ hydrates with higher molar $\mathrm{Si} / \mathrm{Al}$ and $\mathrm{Ca} / \mathrm{Al}$ ratios (50). More recently the effects of lime and barium water treatment on the consolidation of lime mortars were researched (52). The authors compared the traditional lime water technology and barium hydroxide treatment with the consolidation results obtained using distilled water and lime water with added metakaolin in mortars. They concluded that the barium water built a denser and connected substance in lime mortars, which significantly increased the tensile strength of the tested mortars.

\subsubsection{Consolidant products based on $\mathrm{Sr}(\mathrm{OH})_{2}$ nanoparticles}

The synthesis of strontium hydroxide $\left(\mathrm{Sr}(\mathrm{OH})_{2}\right)$ nanoparticles obtained by bottom-up approach, and their use as consolidant product and also as a desulphating agent for stone, mortars and wall paintings were proposed (13). The nanoparticles were dispersed in propan-1-ol solvent and were applied for the consolidation of Lecce limestone (Italy) and for wall paintings (the frescoes of the "Grotta del Crociffiso", Sicily). The authors determined that $\mathrm{Sr}(\mathrm{OH})_{2}$ nanomaterials can react with gypsum, producing strontium sulphate, an insoluble sulfate, that replace the more soluble gypsum and can reduce the mechanical stress. In addition, the carbonation reaction of $\mathrm{Sr}(\mathrm{OH})_{2}$ can produce strontium carbonate $\left(\mathrm{SrCO}_{3}\right)$, which provides the consolidation. Moreover, Licchelli et al. (53) studied the use of $\mathrm{Ca}(\mathrm{OH})_{2}$ nanoparticles and $\mathrm{Sr}(\mathrm{OH})_{2}$ nanoparticles for the consolidation of bioclastic limestones (Lecce stone), and their durability performance, exposing the treated stone specimens to salt crystallization test. They applied the nanoparticles by using capillary absorption and brushing and compared the results obtained with to those observed after the application of tetraethoxysilane (TEOS) on the Lecce stone. They concluded a satisfactory consolidant action of the inorganic nanoparticles compared to the application of TEOS on the stone. Thus, the treatment with $\mathrm{Ca}(\mathrm{OH})_{2}$ and $\mathrm{Sr}(\mathrm{OH})_{2}$ nanoparticles was able to increase the resistance of stone to aging. Besides, the performance of the treatment based on $\mathrm{Ca}(\mathrm{OH})_{2}$ and $\mathrm{Sr}(\mathrm{OH})_{2}$ nanoparticles by brushing results in a deeper penetration and a more homogeneous distribution of the consolidant nanomaterial into the stone substrate (53).

\subsubsection{Silicon dioxide nanoparticles $\left(\mathrm{SiO}_{2}\right)$ applied as consolidant product}

Recently, studies about the behavior of commercial water-based silica dispersions, with different average radius (from 55 to $9 \mathrm{~nm}$ ), as consolidant products on limestone (Lecce stone) have been carried out by Falchi et al. (54). These researchers determined a low penetration depth of the nanosilica dispersions into the stone matrix $(2 \mathrm{~mm})$, and the tendency of silica nanoparticles to form a xerogels layer on the surface of the stone. They proposed that a pre-treatment of the stone surface with ethanol could reduce the stone surface tensions improving the penetration depth and thus resulting in a better consolidant action. In addition, works carried out by Okubo et al. $(55,56)$ showed the influence of the solvent, temperature and humidity in the colloidal crystals of silica spheres (with a diameter of 110 and $103 \mathrm{~nm}$ ) deposited on a cover glass. They determined an important influence of relative humidity and temperature on the macroscopic drying dissipative patterns of colloidal nanosilica (56). Besides, Zornoza-Indart et al. (57) studied the influence of relative humidity in the commercial product Nanoestel ${ }^{\circledR}$, based on an aqueous solution of colloidal $\mathrm{SiO}_{2}$ nanoparticles, and their consolidant action on bioclastic sandstones (calcarenites). The authors have showed that its consolidant action depend strongly on relative humidity. Therefore, compared to the treatment carried out at higher relative 
humidity $(90 \% \mathrm{RH})$, the treatment at lower relative humidity $(40 \%)$ showed an increased efficiency and less adverse changes, marked by less chromatic changes, and no-formation of a cracker layer over the surface stone. Moreover, the effectiveness of consolidation treatments based on a suspension of nanosilica in water and ethyl silicate dispersed in organic solvent applied on a pyroclastic rock were assessed (58). These authors concluded that consolidants increased the resistance of rocks against salt crystallization, although the treatments induced an increase of crystallization pressure.

Nanosilica has been also applied in the field of mortar technology. Zendri et al. (59) studied the reactivity of a colloidal suspension of silica made of particles with an average diameter of $10-15 \mathrm{~nm}$, sodium silicate, and ethyl silicate with calcium carbonate and quartz. These consolidant products form a gel of amorphous silica, which after solvent evaporation are transformed itself in xerogels. Firstly, the authors characterized the three silicatic systems and then, they studied its chemical reactivity mixed with calcite and quartz in 1:1 molar ratio. They determined structural differences on the silica produced by the three consolidants. While the xerogel coming from the colloidal silica formed xerogels with systems mainly related to tri-dimensional systems $\left(Q^{4}\right.$ type $)$, in the xerogels coming from ethyl silicate and sodium silicate prevalence more planar systems $\left(\mathrm{Q}^{3}\right.$ type $)$, highly available for a chemical interaction with calcium carbonate and quartz. Despite the consolidant based on ethyl silicate proves more reactivity than others, measures of cohesion revealed few differences between the products. The porous values and the distribution of the treated and non-treated mortars evidenced a greater penetration capacity of the colloidal silica due to their small dimensions. Furthermore, the research on the science of cementitious materials at nano atomic level is an important research topic. In this field, the incorporation of nano-silica in cementitious mortars has been shown to improve the durability and sustainability of cement-based materials, due to its enhanced reactivity and specific surface area, which results in a high degree of pozzolanic activity $(60,61)$.

\subsubsection{Calcium alkoxides nanoparticles for the stony materials consolidation}

Consolidant products based on metal alkoxides (calcium alkoxides) have been recently proposed (62, 63). It is well known that calcium alkoxides react in presence of atmospheric moisture and carbon dioxide to precipitate metal carbonates nano-structured, and alcohols. The limitation of using these alkoxides as consolidant product is their poor solubility and volatility, which results in a low amount of precipitated carbonates in each application. Recently, and with the objective to increase solubility and stability in metal alkoxides, Ossola et al. (64) and Favaro et al. (65) synthesized calcium alkoxides using starting alcohols sterically hindered (2,2-dimetyl-1-propanol) and/or with additional coordinating atoms by using different synthetic pathways. They determined a strong influence of the alkoxide precursors on the resulting vaterite/calcite ratios generated in contact with the atmosphere. Moreover, the potential effectiveness of alkoxides as consolidant product was tested on Carrara marble by ultrasound measurements. These authors also studied the use of commercial magnesium alkoxides for the conservation of built heritage (65). They determined an unsuitable use of this type of alcoxides applied to stone substrates due to the low crystallinity degree of the obtained coatings and the unsuccessfully carbonation of the $\mathrm{Mg}$ alcoxides into the required phase magnesite.

\subsubsection{Hydroxyapatite for carbonate stone consolidation}

Sassoni et al. (66) were pioneers in the use of hydroxyapatite (HAP) as an alternative to calcium oxalate for the consolidation of carbonate stones used in building heritage. Thus, HAP has been applied for the consolidation of limestones (66), marbles (67), and sandstones with different carbonate contents $(68,69)$. This product is not introduced directly into stone material, but is formed by the reaction between phosphate ions coming from an aqueous solution of diammonium hydrogen phosphate (DAP) applied to the stone and calcium ions coming from the substrate. Among its advantages, HAP has shown a good compatibility with the crystal structure and lattice parameters of calcite (70). Thanks to its low viscosity, this aqueous consolidant product is able to penetrate deeply into the stone, generating a significant improvement in mechanical properties (65) and (66). A comparison with TEOS shows how hydroxyapatite-treated specimens presented an increase in dynamic elastic modulus and a tensile-strength substantially similar to that achieved by TEOS-treated ones. However, differently from samples consolidated with TEOS, hydroxyapatitetreated stones experienced very low variations in porosity and pore size distribution, leading to substantially no variation in the rate of water sorption and a small decrease in water vapor permeability (68). On the other hand, the HAP has been tested as a protective treatment for marble against acid rain corrosion, showing an improvement in the marble resistance to the dissolution $(69,71)$.

Recently, the role of the application technique on the effectiveness of HAP for limestone has been carried out (72). The authors tested the consolidant action of HAP applied by brushing, poultice and immersion on limestone samples artificially 
weathered by heating. They determined the application of HAP by brushing as the most suitable method. This methodological application induced a significant mechanical improvement of limestones with limited microstructural, physical and chromatic alterations (69). Furthermore, Sassoni et al. (73) studied the effectiveness and compatibility of hydroxiapatite treatment for limestone, in comparison with ethyl silicate. The researchers concluded that the hydroxiapatite was able to overcome some ethyl silicate limitations (mainly, prolonging curing time and compatibility), being a very promising consolidant product of porous limestones. They also evaluated the durability of the HAP treatment to wetting-drying, freezing-thawing and salt weathering cycles, in comparison with ethyl silicates (74). Their results showed the HAP as a better option for limestone consolidation compared to ethyl silicates. After the accelerated weathering cycles, the samples treated with HAP underwent less deterioration in original properties than the samples treated with ethyl silicates.

Also, the application of hydroxyapatite and strontium-hydroxyapatite nanoparticles as consolidant product in highly porous limestones (chalk stone) was studied by Ion et al. (75). They determined a higher consolidant activity for the strontium-hydroxyapatite nanomaterial than hydroxyapatite. These authors have also tested a consolidant product based on hydroxyapatite jointed with calcium oxalate trihydrate (caoxite) on weathered chalk stone (76), and concluded that the caoxite induced the stabilization of the hydroxyapatite and their mixed composition produced an important reinforcement of chalk stone after accelerated weathering tests.

\subsection{Silicon-based hybrid polymer nanocomposites}

\subsubsection{Surfactant-synthesized silicon-based hybrid nanocomposites applied to stony materials}

Alkoxysilane-based formulations, and specially methyltrimethoxysilane (MTMOS) and tetraethoxysilane (TEOS), have been the most widely used stone consolidants mainly due to their ability to penetrate easily into porous matrix. These consolidants are absorbed by the stone, hydrolyzed by water to form silanols, which then polymerise in a condensation reaction and form a polymer that increase the cohesion of the stone material (77). Thus, silicon based-consolidants can be considered as fairly compatible with silicate stones, at least in terms of chemical-mineralogical composition, since TEOS is expected to fully convert into amorphous silica once the hydrolysis/condensation reaction has been completed. Despite these materials have improved physical, chemical and mechanical properties, the alkoxysilanes present important disadvantages, such as their tendency to form brittle gels susceptible to crack during shrinkage and drying and their inefficient chemical bonding to carbonaceous stones (78). As noted by Mosquera el al. (79) cracking is generated by the high capillary pressures supported by the gel network during drying. Smaller pores are subject to higher pressure than larger pores. Thus, dense gels containing micropores, typically obtained from TEOS, are susceptible to cracking.

In order to minimize the tendency to crack of TEOS, novel nanomaterials have been synthesized by a synthesis strategy in which the sol-gel transition is carried out in the presence of a non-ionic surfactant (n-octylamine). The n-octylamine acts as a template to make the pore size of the gel network uniform, and as a basis catalyst of the soltransition on the stone surface. In this way, the cracking of consolidants is successfully prevented (80). These new consolidant products have been tested in sedimentary and metamorphic rocks and more recently, in granite (81). In this last work, the authors defined the application protocol and commercial requirements for their application to exterior conditions. The addition of a small amount of surfactant during the preparation of the nanocomposites in order to obtain crack-free consolidants for stone conservation has also been employed by other researchers (82). Furthermore, ZornozaIndart et al. (83) evaluated the consolidant action of a nanostructured consolidant developed by Illescas et al. (78) composed by a silica oligomer precursor Wacker TES $40 \mathrm{WN}^{\circledR}$ with the addition of n-octylamine as a surfactant, under different environmental conditions (dry, $R H=40 \pm 2 \%$, and very humid conditions, $R H=84 \pm 2 \%$ and $95 \pm 2 \%$ ). They determined an increased consolidant effectiveness in the stone specimens treated in the very humid consolidation environment. They also detected negative results concerning to the chromatic changes obtained in the treated substrates, marked by a visually change by the shift to yellow color.

\subsubsection{Particle-modified silica consolidants (PMC) for the stone materials}

Another approach that has been developed in order to optimize the gel phase physical properties is to reduce the cracking of the consolidant products through the addition to different metal colloidal oxides particles to the TEOS-based polymeric resins $(84,85)$. The loading of colloidal oxide particles to TEOS has shown to enlarge the pore size within the network and increases the modulus, resulting in a lower capillary pressure (86). Also, the excessive agglomeration can be prevented through the modification of the final gel by absorbing nanoparticles onto the oxide particles (87). In this way, the development of 
nano particle-modified silica consolidants, allow reducing the cracking seen in conventional treatments and improve the consolidation. In order to avoid color problems that usually leave a whitish surface on the material Miliani et al. (85) studied the incorporation of oxide nanoparticles $(\sim 200$ $300 \mathrm{~nm}$ ) to the initial silicate network (TEOS) for the consolidation of Ohio Massilian sandstones. These consolidant products consisted of a silicate binder loaded with alumina $\left(\mathrm{Al}_{2} \mathrm{O}_{3}\right)$, titania $\left(\mathrm{TiO}_{2}\right)$, and silica $\left(\mathrm{SiO}_{2}\right)$ nanoparticles. PMCs provided a remarkable protection against salt damage. However, the $\mathrm{TiO}_{2}-\mathrm{PMC}$ application caused an unacceptable color change on Ohio sandstone. Nevertheless, alumina and silica provided composites giving color changes near the threshold. Anyway, particle-modified consolidants offered substantially improved properties compared with the unfilled ethyl silicate consolidant, particularly with respect to protection from salt crystallization damage (85).

The use of nanoparticle loading in polymeric resins with enhanced photoactivity for self-cleaning and protection applications on building materials will be discussed further below.

\subsubsection{Calcium oxalate-Silica nanocomposites applied to calcareous substrates and mortars}

Recently, Verganelaki et al. (88), proposed a novel crack free calcium oxalate-silica nanocomposite for protecting both historic and modern building materials. The nanocomposite was obtained by using two-step sol gel method consisting in the reaction of calcium hydroxide with oxalic acid, followed by its loading into TEOS. Therefore, nanoparticles of calcium oxalate were mixed with TEOS to produce a crack-free xerogel with an average pore radius of approximately $15 \mathrm{~nm}$ (88). Among the advantages of these new nanocomposites is the use of calcium oxalate, compound identified in historical patina layers on monuments (89). In addition, the formation of a stable component composed of calcium oxalate and silica is a well-established process in plant biomineralization (88). The authors concluded that the proposed hybrid nanocalcium oxalate-silica reached a penetration depth of more than $1 \mathrm{~cm}$ from the surface of the treated stone without altering its microstructure, and improving its tensile strength. Results indicated also that the changes in water permeability and total color produced by the treatment were within acceptable limits.

More recently, these researchers showed the optimization of the synthesis route by the formation of nano-calcium oxalate simultaneously with the polymerization of TEOS via one-pot sol-gel method (90). The new nanocomposite incorporated particles of synthesized amorphous nano-calcium oxalate monohydrate in a silica matrix, obtaining a microporous hybrid material with an average pore diameter of $2.73 \mathrm{~nm}$. The consolidation effectiveness of the method was evaluated in calcareous building stones and cement mortars. They conclude the optimal penetration depth of the nanocomposite into the substrates without occluding the pores with crack-free microstructure, and improving the mechanical properties of the treated limestones and cement mortars. The incorporation of amorphous nanocalcium oxalate into the silica matrix provided a good interfacial compatibility between the nanocomposite and the carbonaceous stones. Furthermore, the nanocomposites showed good stability under conditions of high relative humidity $(90 \%)$ and UV irradiation.

\section{WATER REPELLENTS NANOMATERIALS}

The hydrophobic character of synthetic polymers, such as hybrid siloxanes or silicone polymers, can be enhanced by incorporation of inorganic oxide nanoparticles, such as silicon dioxide $\left(\mathrm{SiO}_{2}\right)$, aluminum oxide $\left(\mathrm{Al}_{2} \mathrm{O}_{3}\right)$, tin dioxide $\left(\mathrm{SnO}_{2}\right)$, and titanium dioxide $\left(\mathrm{TiO}_{2}\right)$, which present a high waterrepellent capacity, generating superhydrophobic coatings (91).

Thus, during the last years, the use of polymeric materials with hydrophobic properties has been widely studied (Figure 5). In this context, the preparation of polymer-nanoparticles composites has involved a significant contribution in the conservation of stone cultural heritage due to the important advantages of these new nanocomposites (higher surface area available and small particle size) (92-99).

Superhydrophobic surfaces exhibit certain wetting characteristics originating from very high static contact angles $\left(>150^{\circ}\right)$ and very small values of contact angle hysteresis $\left(<10^{\circ}\right)(91,100,101)$. Hysteresis is directly related to the force required for a drop starts to move or sliding on a surface (102) providing its water repellency (103). These superhydrophobic properties can be achieved through the incorporation of nanoparticles into the composites matrix (104), which modifying the chemical properties of material surfaces, reducing the chemical free energy or increasing the superficial roughness $(105,106)$. The influence of surface roughness on the behavior of water over the surfaces has been studied by CassieBaxter (107). A good treatment efficacy is achieved when the average values of superficial roughness are in the range of 125 to $150 \mathrm{~nm}(108)$. The surface roughness of the treated surfaces is marked by the particle sizes and the aggregation level of nanoparticles (9). In addition, the increase in the concentration of nanoparticles brings higher roughness values, which promotes their water repellency capacity. This is why the contact angle is increased with the decrease of contact angle hysteresis to values of below $5^{\circ}(104)$, providing its water repellent degree. 

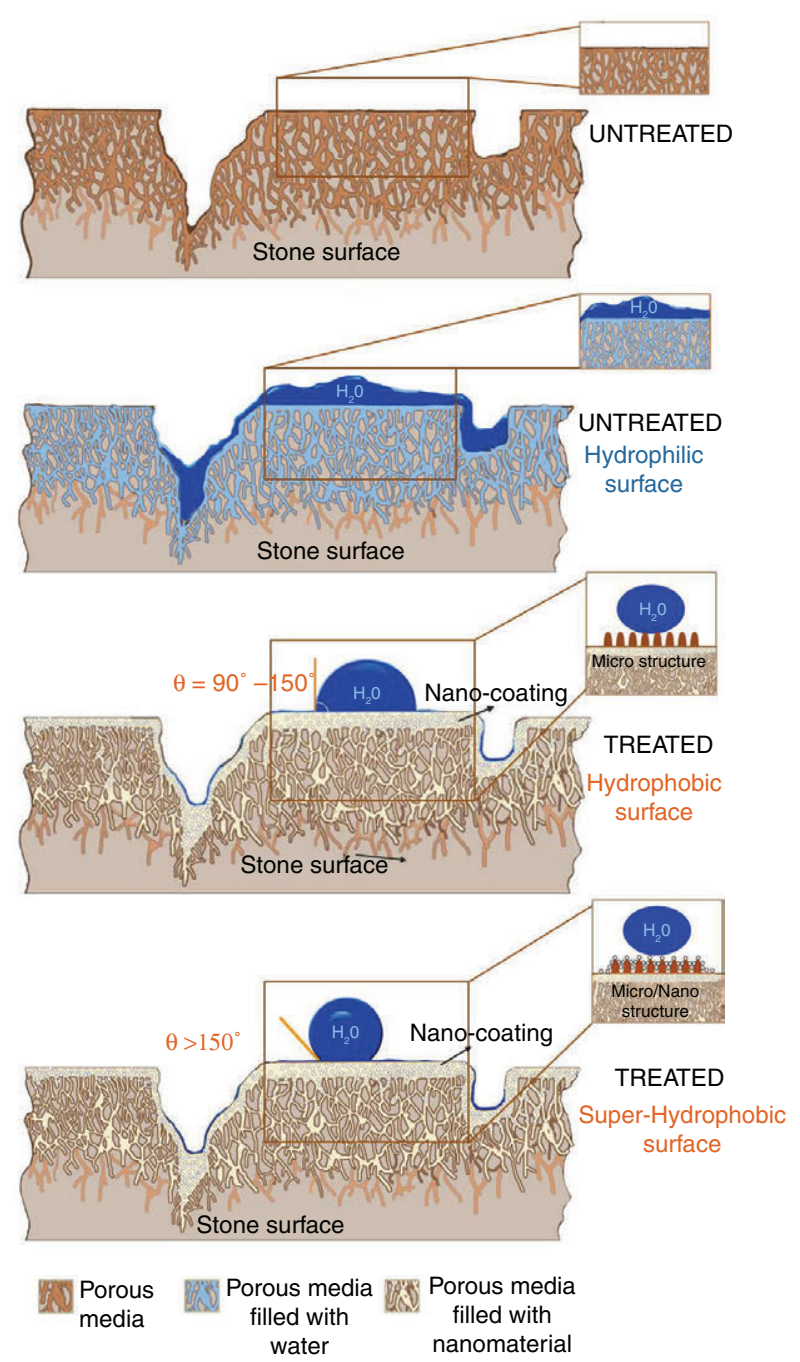

FIGURE 5. Static contact angle of a water drop of untreated (a) and (b) treated limestone by a water repellent product.

One important point in the use of nanoparticles polymer composites on the patrimonial stoneworks is to take into account the changes that can generate the presence of nanoparticles in the polymer matrix during the polymerization process (109). Works carried out by Lampakis et al. (110) detected that the polymerization is not influenced by the presence of nanoparticles.

In this context, relevant superhydrophobic materials have been developed in recent years by the reduction of the surface free energy and roughening the surface. Acrylics, fluorinated acrylic polymers, siloxanes and fluoropolyethers are usually employed as protective coatings. Recently, De Ferri et al. (95) obtained superhydrophobic products for stoneworks, by mixing alkoxysilanes and silica particles synthesized by sol-gel route using $\mathrm{HCl}$ as a catalyst and ethanol as a solvent. In addition, Mosquera et al. (79), synthesized a new water repellent product by adding an organosiloxane
PDMS (polydimethylsiloxane), to tetraethoxysilane (TEOS) sol in the presence of n-octylamine as surfactant. Thus, an organic-inorganic hybrid material with high elasticity was obtained through the cocondensation of TEOS and PDMS. These hydrophobic products were shown to improve the robustness, hydrophobicity, water repellence, and stain resistance of the stone substrates (78, 111). Most recently, D.S. Facio et al. (9) produced superhydrophobic nanocomposites by mixing silica nanoparticles with a silica oligomer and a low-molecular weight organic siloxane in presence of a surfactant. The nanocomposite was applied on sandstone and produced a homogeneous coating with hydrophobic and repellence properties to the stone, preserving the aesthetic qualities of the stone substrate. The authors showed that the addition of $\mathrm{SiO}_{2}$ nanoparticles is a key factor for improving the hydrophobic properties of the nanocoatings (9).

Works carried out by B.J Sparks et al. (112) showed the development of superhydrophobic hybrid inorganic organic thiol-ene surfaces obtained by spray-deposition and photopolimerization. The spray process provided a hierarchically structured surface stabilized by cross-linking the resin via thiol-ene photo-polimerization. Subsequently, Xiong et al. (113) created superamphiphobic surfaces by introducing a fluorinated multifunctional thiol into the thiolene formulation. Droplet impact and sandpaper abrasion tests indicated that the coating possessed a robust antiwetting behavior and good mechanical durability. Recently, Pedna et al. (114) produced homogeneous coatings composed by $\mathrm{SiO}_{2}$-fluorinated PLA composites highly hydrophobic and reversible for the protection of building materials.

On the other hand, it is important to take into account not only the water repellency capacity of the treatment, but also the petrophysical properties of the treated stone substrates and the durability of the treatments in order to prevent damage to the stone heritage (115). Also, the nanomaterial must preserve the esthetic properties of the stone substrate. Therefore, transparency and absence color are important requirements for products that must be invisible color. Manoudis et al. (92) observed color changes in treated stone by akylsiloxane modified with different types of nanoparticles. However, other authors have not observed significant changes in stone treated with polydimethylsiloxane and $\mathrm{SiO}_{2}$ nanoparticles (9). Furthermore, the treated stone must maintain its permeability to water vapor and the decrease in its ability to absorb water by capillarity (93). It is crucial to assess the durability of the hydrophobic nanomaterials in order to ensure that its water repellent properties are maintained over time (116). 


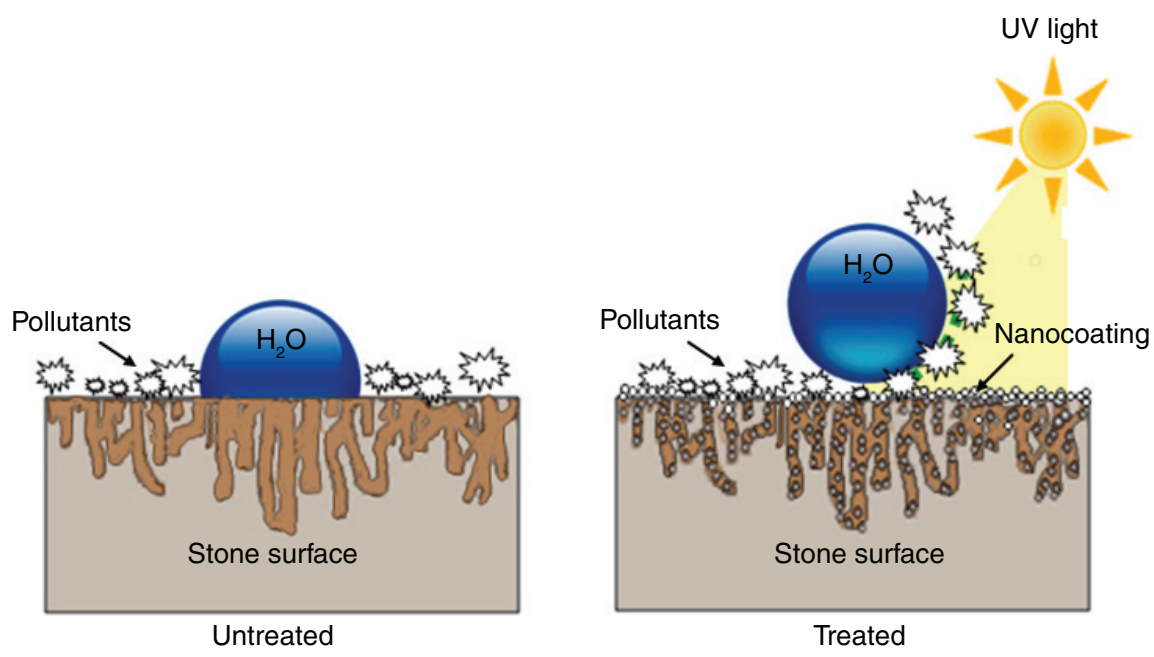

FIGURE 6. Schematic illustrations of self-cleaning processes on untreated and treated stone surfaces.

\section{PROTECTIVE TREATMENTS}

\subsection{Self-cleaning coatings}

The $\mathrm{TiO}_{2}$ in the anatase form is widely used for self-cleaning applications, due to their photocatalytic properties for the destruction of organic pollutants (117). Apart from its high stability, good performance and low cost (118), it has hydrophilic and amphiphilic properties. The photocatalysis and hydrophilicity can take place simultaneously on the same surface even though the mechanisms are completely different (119).

When photocatalyst $\mathrm{TiO}_{2}$ absorbs Ultraviolet (UV) radiation from sunlight or illuminated light source (fluorescent lamps), it will produce pairs of electrons and holes. The free radicals or electrons that result react with foreign substances on the surface and produce chemical reactions that ultimately decompose the foreign substances through oxidation. Organic matter can be quickly decomposed. The loosened and decomposed material can then be washed away by normal rainfall or other means (Figure 6). Since bacteria formation is associated with organic matter, the washing away of this matter also causes the surfaces to have antibacterial qualities (120). However, the particle size is a clue factor in photocatalysis performance, $(121,122)$ being necessary to determine an optimal particle size for obtaining the maximum photocatalytic efficiency.

$\mathrm{TiO}_{2}$ acts against the onset of degrading processes due to stain, biological attacks and pollution molecules such as NOx, SOx, BTX (123-126). Photocatalysis plays an important role in maintain the self-cleaning effect through two ways: decomposing the soiled compounds into $\mathrm{H}_{2} \mathrm{O}, \mathrm{CO}_{2}$ and organic compounds to acquire self-cleaning effect directly, and decomposing the soiled compounds to recover the hydrophilicy and acquiring self-cleaning effect indirectly (126).

The trend nowadays is to develop hybrid materials which promote simultaneously photocatalytic action and thus serve as self-cleaning, biocidal and for mechanical strengthening. These materials alter the surface and thus the contact angle, so that may protect from the action of water. This is the case of combining powders or suspensions of $\mathrm{TiO}_{2}$ with $\mathrm{SiO}_{2}$, polymers, oligomers or silicon alkoxides.

Nano $\mathrm{TiO}_{2}$ is commercialized for its application in marbles, limestones and dolostones. However, its efficiency is different depending on the synthesis procedure used (127-129) or by its application method (spray coating (130), brushing $(131,132))$. When it is used in single-layer or multilayer treatments as in travertine samples, has shown good compatibility and photocatalytic efficiency. The hydrophilic effect is partially reduced by weathering, without apparent damages in the stone substrate (133). The de-polluting activities of $\mathrm{TiO}_{2}$ in $\mathrm{NOx}$ degradation (128), has demonstrated good compatibility with limestone surfaces and efficiency, for outdoor applications.

The incorporation of polymeric matrices for dispersing the $\mathrm{TiO}_{2}$ represents a coating technology with hydrophobic, consolidating and biocidal properties (96). Some products (Fosbuild FBLE 200), applied in limestones and marbles present biocidal effectiveness (96), Although, after aging, limestone treated seem to be not affected by solar radiation; conversely, for marble, the coating is almost ineffective (96).

The combination of oligomers and $\mathrm{TiO}_{2}$ nanoparticles for obtaining mesoporous titaniasilica composites with photocatalytic properties, (ethoxysilane oligomers mixed with $\mathrm{TiO}_{2}$ in the presence of a nonionic surfactant) have resulted to be an effective adhesive with crack-free coatings for 
stone. These coatings give self-cleaning properties to stone, improving its mechanical resistance and giving hydrophobic properties (134).

$\mathrm{TiO}_{2}$ mixed with a silica sol interlayer (TEOS as precursor) is used for limestone protection. Promising results are reported for application in calcarenites (131), although with slight darkening of the surface, when impurities of brookite are present. In this case, the coatings do not alter the capillary absorption of water, conserving the stone characteristics, but do not prevent the salts crystallization (129). Moreover, multifunctional products, combining $\mathrm{TiO}_{2}$ (photocatalytic) with fluorinated polymer (hydrophobic), improve the materials durability (125). In addition to immobilize the $\mathrm{TiO}_{2}$ in the polymer, prevent the release of the $\mathrm{TiO}_{2}$ from the surface to the environment (125).

In clay brick surfaces, the inhibitory effect of $\mathrm{TiO}_{2}$ nanocoatings against microalgal growth under weak UV exposure conditions is not effective. But, under optimal UV exposure conditions prevents the adhesion of microorganisms on the treated substrates (135).

Very few studies with $\mathrm{TiO}_{2}$ nanoparticles have been conducted so far to remedy the problems of pollution in mortars. One of them shows how the efficacy varies depending on the way of application, either as suspension, as powder or mixed. However adhesion problems in the surface layer have been observed. Furthermore, high content of anatase would be necessary for having a good performance, which would result very expensive (136). However, photocatalytic mortars can be applied in new and old buildings, because the nanoadditives do not compromise the mortar hardened state properties. Nevertheless, its effectiveness must be controlled taking into account the mortars microstructure (pore size and distribution), the optimal catalyst content, the position respect to the sun light and the time of exposure (137).

\subsection{Antimicrobial stone coatings}

Biodeterioration is one of the main degradation processes of outdoor stone heritage. The microorganisms are involved in the deterioration of stone due to the fact that they secrete enzymes and organic acids during their metabolic processes, highly harmful for the stone heritage. Thus, in recent years important studies have been centered on innovative strategies consisting in the application of the combination of consolidants, water repellents, and nanoparticles with antimicrobial activity. In this context, nanostructured metal oxides might be an effective tool for controlling the biodeterioration because present great advantages (high surface to volume ratio, small particle size, and longer lifetimes (138).
The possibility of embedding copper $(\mathrm{Cu})$ nanoparticles in polymer matrices in order to obtain preservative treatments against biological growth for stone heritage has been reported by different authors (139-141). In this way, Quaresima et al. (138) studied the application of organic matrixes containing $\mathrm{Cu}$ oxide nanoparticles to prevent the growth of algae and bacteria in fountains. Most recently, Pinna et al. (142) researched the antimicrobial effectiveness of the mixtures of consolidants or water repellent products with $\mathrm{Cu}$ nanoparticles on different stones (marble, sandstone and plaster), determining the ability to prevent the biological growth of these mixtures for three years. Also, it is important to take into account that the dark color of the copper nanoparticles colloids could limit their application on light-color stone substrates, being necessary to use low amounts of $\mathrm{Cu}$ nanoparticles in order to avoid this problem.

On the other hand, the use of silver (Ag) nanoparticles as antimicrobial coatings for stone heritage has been studied in recent times. Silver is widely used as a strong antimicrobial for a long time. In the field of cultural heritage, the capacity of silver nanoparticles grafted to Italian Serena sandstone surfaces to inhibit bacterial viability has been studied by (143). The nanoparticles were functionalized through the condensation of a silane precursor (tetraethylorthosilicate, TEOS) on the surface of Ag nanoparticles, and showed an effectiveness ranging from 50 to $80 \%$ in reducing cell viability. Aflori et al. (144) developed antibacterial and antifungal coatings based on two silsesquioxane-based hybrid nanocomposites with methacrylate units modified with titania and/or silver nanoparticles. These authors concluded that the silsesquioxane-based hybrid nanocomposites containing titania nanoparticles showed a higher antibacterial/antifungal activity against $E$. coli and C. albicans. Most recently, Carrillo-González et al. (145) synthesized silver nanoparticles from leaf extracts, and studied their effectiveness in controlling bacteria and fungi in vitro as well as on different types of stones (stucco, basalt and calcite) widely applied to cultural heritage. They determined the silver nanoparticles as promising antimicrobial agents for cultural heritage conservation highly dependent on the selected doses.

Also, nanostructured zinc oxide $(\mathrm{ZnO})$ has shown to be bio-safe and bio-compatible and possesses antibacterial and antifungal activity due to their surface-chemical activity (146). These nanoparticles are white-colored and should better meet the aesthetic requirements for application in the field of conservation of cultural heritage. Thus, I.D. Van der Werf et al. (147) demonstrated that higher $\mathrm{ZnO}$ nanoparticles loadings could be achieved without affecting the color of the stone substrates. Recently, Ditaranto et al. (148) developed bioactive nanocomposite systems composed by a water repellent/ 
consolidant product and zinc oxide nanoparticles in various $\% \mathrm{w} / \mathrm{w}$ concentrations for the protection of stone heritage. The $\mathrm{ZnO}$-based nanocomposites were applied on calcareous stones and the bioactivity of the nanocomposites was assessed against $A$. niger fungus. The nanocomposites proved to be stable after more than one year of application. For stone conservation, Gómez-Ortiz et al. (149) developed $\mathrm{Ca}(\mathrm{OH})_{2}$ mixed with $\mathrm{ZnO}$ and $\mathrm{TiO}_{2}$ nanoparticles. The ZnO-based systems showed the best antifungal properties against $P$. oxalicum and $A$. niger under simulated photoperiod conditions. In addition, protective coatings containing calcium zinc hydroxide dihydrate $\left(\mathrm{Ca}\left[\mathrm{Zn}(\mathrm{OH})_{3}\right]_{2} \cdot 2 \mathrm{H}_{2} \mathrm{O}\right)$ were prepared by sol-gel method and their antifungal properties were studied on different limestone substrates (150). The system showed important antifungal properties under photoperiods of dark and illumination, keeping its antifungal properties after 21 days of inoculation. In addition, Ruffolo et al. (151) studied the biocidal activity of $\mathrm{ZnO}$ and $\mathrm{ZnTiO}_{3}$, and its application dispersed in different polymeric matrices (acrylic and fluorinated) on marble samples to obtain coatings with hydrophobic, consolidant and biocidal properties for the stone conservation. The $\mathrm{ZnO}$ and $\mathrm{ZnTiO}_{3}$ showed potential antifungal activity against Aspergillus niger, revealing a higher antifungal efficiency of the $\mathrm{ZnTiO}_{3}$ than $\mathrm{ZnO}$. Moreover, Ruffolo et al. (152) studied the use of $\mathrm{TiO}_{2}$ and Ag-doped $\mathrm{TiO}_{2}$ synthesized by solgel method as antifouling agents applied to stone conservation. The different nanoparticles were dispersed in a polymer and then were applied to marble surfaces, showing a decreasing of antifungal activity on treated stone surfaces. M.F. La Russa et al. (153) studied the antifungal activity of alkaline earth metal ions (silver (Ag), iron (Fe), and Strontium (Sr) and mix) doped $\mathrm{TiO}_{2}$. Their results showed that $\mathrm{Ag}$, $\mathrm{Fe}$, and $\mathrm{Sr}$ increased the $\mathrm{TiO}_{2}$ activity against biodeterioration, revealing their successful application for stone conservation of outdoor, indoor and marine archaeological items as potential biocide.

\section{CONCLUDING REMARKS}

The use of nanotechnology applied to the stone heritage conservation field creates possibilities to produce conservation treatments with enhancing material properties and novel functionalities. These nanomaterials include important advantages that could solve many problems found in the traditional interventions through the development of new nanomaterials or the improvement of the traditional treatments with the incorporation of nanoparticles. In this way, as has been described in the work, innovative applications have reached by using nanoparticles in building materials such as stone deterioration, environmental pollution remediation and self-cleaning and anti-microbial effect.
Thus, nanotechnology has been shown to have an important impact in the cultural heritage and construction sector, improving the durability and enhanced performance of construction materials, energy efficiency and safety of the monuments.

It is essential to examine the behaviour and the stability of the nanoparticles obtained when exposed to environmental factors as the relative humidity, time of exposition and $\mathrm{CO}_{2}$ concentration. Moreover, an exhaustive knowledge of the petrophysical properties of the stone materials and their durability before and after the treatments by nanoparticles are crucial factors to take into account in order to assess the effectiveness treatments. This knowledge is crucial when designing and implementing the interventions and materials for the safeguard of cultural heritage.

Finally, it can be pointed out that the study of the effectiveness, compatibility and durability of these new nanomaterials are necessary in order to avoid the use of inadequate treatments, which modify the aesthetic, physical and chemical properties of stony materials, causing new pathologies. Also, the knowledge of the industrial production, the capacity utilization, and the price of raw materials are important aspects need to be considered. The human health risks and environmental implications resulting from the use of the new nanomaterials should be taken into account when designing treatments based on nanoparticles.

\section{ACKNOWLEDGMENTS}

This study has been supported by the Autonomous Region Program of Madrid the Geomateriales 2 (s2013/MIT_2914) and Multimat-Challenge (S2013/ MIT-2862), the Innovation and Education Ministry (Climortec, BIA2014-53911-R and MAT201347460-C5-5-P) the Complutense University of Madrid's Research Group: "Applied Petrology for Heritage Conservation Research Group (921349) and the Carlos III University of Madrid's Research Group: "Powder Technology-UC3M".

\section{REFERENCES}

1. Giorgi, R.; Dei, L.; Baglioni, P. (2000) A new method for consolidating wall paintings based on dispersions of lime in alcohol. Stud. Conserv., [45], 154-161. http://dx.doi. org/10.1179/sic. 2000.45.3.154.

2. Dei, L.; Salvadori, B. (2006) Nanotechnology in cultural heritage conservation: nanometric slaked lime saves architectonic and artistic surfaces from decay. J. Cult. Herit., [7], 110-115. http://dx.doi.org/10.1016/j.culher.2006.02.001.

3. Manoudis, P.; Papadopoulou, S.; Karapanagiotis, I.; Tsakalof, A.; Zuburtikudis, I.; Panayiotou, C. (2007) Polymer-Silica nanoparticles composite films as protective coatings for stone-based monuments. J. Phys Conf Ser., [61], 1361-1365. http://dx.doi.org/10.1088/1742-6596/61/1/269.

4. Linsebigler, A.; LLu, G.; Yates, J.T. (1995) Photocatalysis on $\mathrm{TiO}_{2}$ surfaces: principles, mechanisms, and selected results. Chem. Rev., [95], 735-758. http://dx.doi.org/10.1021/ cr00035a013. 
5. Munafò, P.; Battista Goffredo, G.; Quaglirini, E. (2015) $\mathrm{TiO}_{2}$-based nanocoatings for preserving architectural Stone surfaces: An overview. Constr. Build. Mater., [84], 1:201-218. http://dx.doi.org/10.1016/j.conbuildmat.2015.02.083.

6. Abd Aziz, A.; Kaan Cheng, C.; Ibrahim, S.; Matheswaran, M.; Saravanan, P. (2012) Visible light improved, photocatalytic activity of magnetically separable titania nanocomposite. Chem. Eng. J., [183], 349-356. http://dx.doi. org/10.1016/j.cej.2012.01.006.

7. Kapridaki, C.; Pinho, L.; Mosquera, M.J. (2014) Producing photoactive, transparent and hydrophobic $\mathrm{SiO}_{2}$-crystalline $\mathrm{TiO}_{2}$ nanocomposites at ambient conditions with application as self-cleaning coating. Appl. Catal. B., [156-157], 416-427. http://dx.doi.org/10.1016/j.apcatb.2014.03.042

8. Colangiuli, D; Calia, A; Bianco, N. (2015) Novel multifunctional coatings with photocatalytic and hydrophobic properties for the preservation of the stone building heritage. Constr. Build. Mater., [93], 189-196. http://dx.doi. org/10.1016/j.conbuildmat.2015.05.100.

9. Facio, D.S.; Mosquera, M.J. (2013) Simple strategy for producing superhydrophobic coatings in situ on a building substrate. ACS Appl. Mater. Interfaces, 5 [15], 7517-26. http://dx.doi.org/10.1021/am401826g.

10. Mohammad Rabea, A.; Mohseni, M.; Mirabedini, S.M.; Hashemi Tabatabaei, M. (2012) Surface analysis and antigraffiti behaviour of a weathered polyurethane-based coating embedded with hydrophobic nano silica. Appl. Surf. Sci., 258 [10], 4391-4396. http://dx.doi.org/10.1016/j. apsusc.2011.12.123.

11. Licchelli, M.; Malagodi, M.; Weththimuni, M.; Zanchi, C. (2014) Anti-graffiti nanocomposite materials for a surface protection of a very porous stone. Appl. Phys. A Mater. Sci. Process., 116 [4], 1525-1539. http://dx.doi.org/10.1007/ s00339-014-8356-9.

12. Gruyaert, E.; Van Tittelboom, K.; Sucaet, J.; Anrijs, J.; Van Vlierberghe, S.; Dubruel, P.; G. De Geest, B.; Remon J-P.; De Belie, N. (2016) Capsules with evolving brittleness to resist the preparation of self-healing concrete. Mater. Constr., 66 [323], e092. http://dx.doi.org/10.3989/mc.2016.07115.

13. Ciliberto, E.; Condorelli, G.G.; La Delfa, S; Viscuso, E. (2008) Nanoparticles of $\mathrm{Sr}(\mathrm{OH})_{2}$ : synthesis in homogeneous phase at low temperature and application for cultural heritage artefacts. Appl. Phys. A-Mater. Sci. Process., 92 [1], 137-141. http://dx.doi.org/10.1007/s00339-008-4464-8.

14. Danielle, V.; Taglieri, G.; Quaresima, R. (2008) The nanolimes in cultural heritage conservation: characterization and analysis of the carbonation process, J. Cult. Herit., 9 [3], 294-301. http://dx.doi.org/10.1016/j.culher.2007.10.007.

15. Ziegenbalds, G. (2008) Colloidal calcium hydroxide: a new material for consolidation and conservation of carbonate stone, En: $11^{\text {th }}$ International congress on deterioration and conservation of stone III, 1109

16. Gomez-Villalba, L. S.; López-Arce, P.; Zornoza-Indart, A.; Alvarez de Buergo, M.; Fort, R. (2012, April) Modern restoration products based on nanoparticles: The case of the Nano-Lime, interaction and compatibility with limestone and dolostones surfaces, advantages and limitations. In $E G U$ General Assembly Conference Abstracts, (Vol. 14, p. 2418)

17. López-Arce, P.; Gomez-Villalba, L.S.; Martínez-Ramírez, S.; Álvarez de Buergo, M.; Fort, R. (2011) Influence of relative humidity on the carbonation of calcium hydroxide nanoparticles and the formation of calcium carbonate polymorphs. Powder. Technol., 205 [1], 263-269. http:// dx.doi.org/10.1016/j.powtec.2010.09.026.

18. López-Arce, P.; Gomez-Villalba, L.S.; Pinho, L.; FernándezValle, M.E.; Álvarez de Buergo, M.; Fort, R. (2010) Influence of porosity and relative humidity on consolidation of dolostone with calcium hydroxide nanoparticles: effectiveness assessment with non-destructive techniques. Mater. Charact., [61], 168-184. http://dx.doi.org/10.1016/j. matchar.2009.11.007.

19. Gómez, L.S.; López-Arce, P.; Álvarez de Buergo, M.; Fort, R. (2009) Calcium hydroxide nanoparticles crystallization on carbonates stone: dynamic experiments with heating/cooling and Peltier stage ESEM. Acta Microsc., [18], 105-106. ISSN 0798-4545
20. Rodríguez-Navarro, C., Vettori, I., Ruiz-Agudo, E. (2016) Kinetics and mechanism of calcium hydroxide conversion into calcium alkoxides: Implications in heritage conservation using nanolimes. Langmuir, 32 [20], 5183-5194. http:// dx.doi.org/10.1021/acs.langmuir.6b01065.

21. Daniele, V.; Taglieri, G. (2010) Nanolime suspensions applied on natural lithotypes: the influence of concentration and residual water content on carbonatation process and on treatment effectiveness. J. Cult. Herit. 11 [1], 102-106. http://dx.doi.org/10.1016/j.culher.2009. 04.001 .

22. Gómez-Villalba, L. S.; López-Arce, P.; Fort, R. (2012) Nucleation of $\mathrm{CaCO}_{3}$ polymorphs from a colloidal alcoholic solution of $\mathrm{Ca}(\mathrm{OH})_{2}$ nanocrystals exposed to low humidity conditions. Appl. Phys. A, 106 [1], 213-217. http:// dx.doi.org/10.1007/s00339-011-6550-6.

23. Gomez-Villalba, L. S., López-Arce, P., de Buergo, M. A., Zornoza-Indart, A., Fort, R. (2013) Mineralogical and textural considerations in the assessment of aesthetic changes in dolostones by effect of treatments with $\mathrm{Ca}(\mathrm{OH})_{2}$ nanoparticles. Science and Technology for the Conservation of Cultural Heritage, 235-329.

24. Sierra-Fernández, A.; Gómez-Villalba, L.S.; Milosevic, O.; Fort, R.; Rabanal, M.E. (2014) Synthesis and morphostructural characterization of nanostructured magnesium hydroxide obtained by a hydrothermal method. Ceram. Int., [40], 12285-12292. http://dx.doi.org/10.1016/j. ceramint.2014.04.073.

25. Gómez-Villalba, L.S.; López-Arce, P.; Álvarez de Buergo, M.; Fort, R. (2012) Atomic defects and their relationship to aragonite-calcite transformation in portlandite nanocrystal carbonation. Cryst. Growth Des., 12 [10], 4844-4852. http:// dx.doi.org/10.1021/cg300628m.

26. López-Arce, P.; Zornoza-Indart, A. (2015) Carbonation acceleration of calcium hydroxide nanoparticles: induced by yeast fermentation. Appl. Phys. A., 120 [4], 1475-1495. http://dx.doi.org/10.1007/s00339-015-9341-7.

27. Hansen, E.; Doehne, E.; Fidler, J.; Larson, J.; Martin, B.; Matteini, M.; Rodríguez-Navarro, C.; Sebastian Pardo, E.; Price, C.; de Tagle, A.; Teutonico, J.-M, Weiss, N.R. (2003) A review of selected inorganic consolidants and protective treatments for porous calcareous materials. Reviews in Conservation, [4], 13-25. http://dx.doi.org/10.1179/ sic.2003.48.Supplement-1.13.

28. Gómez-Villalba, L.S.; López-Arce, P.; Álvarez de Buergo, M.; Fort, R. (2011) Structural stability of a coloidal solution of $\mathrm{Ca}(\mathrm{OH})_{2}$ nanocrystals exposed to high relative humidity conditions. Appl. Phys. A., 104, [4], 1249-1254. http://dx.doi.org/10.1007/s00339-011-6457-2.

29. López-Arce, P.; Zornoza-Indart, A.; Gómez-Villalba, L.S.; Fort, R. (2012) Short-and Longer-Term Consolidation Effects of Portlandite $(\mathrm{CaOH})_{2}$ Nanoparticles in Carbonate Stones. J. Mater. Civil Eng., 25 [11], 1655-1665. http://dx.doi.org/10.1061/(ASCE)MT.1943-5533. 0000740.

30. Gómez-Villalba, L.S.; López-Arce, P.; Zornoza, A.; Alvarez, De Buergo, M.; Fort, R. (2011) Evaluation of a consolidation treatment in dolostones by mean of calcium hydroxide nanoparticles in high relative humidity conditions. Bol. Soc. Esp. Ceram. V., 50 [2] 85-92. http://dx.doi. org/10.3989/cyv.122011.

31. Sierra-Fernández, A.; Gómez-Villalba, L.S.; Rabanal, M.E.; Fort, R. (2014) New consolidant product based on nanoparticles to preserve the dolomitic Stone heritage. M. Rogerio Candelera (Ed.), Science, Technology and Cultural Heritage, pp. 139-144. ISBN 9781315712420.

32. Arizzi, A.; Gómez-Villalba, L.S.; López-Arce, P.; Cultrone, G.; Fort, R. (2015) Lime mortar consolidation with nanostructured calcium hydroxide dispersions: the efficacy of different consolidating products for heritage conservation. Eur. J. Mineral., [27], 311-323. http://dx.doi. org/10.1127/ejm/2015/0027-2437.

33. Drdácký, M.; Slížková, Z.; Ziegenbalg, G. (2009) A nano approach to consolidation of degraded historic lime mortars, J. Nano Res., [8], 13-22. http://dx.doi.org/10.4028/ www.scientific.net/JNanoR.8.13. 
34. Borsoi, G.; Tavares, M.; Veiga, R.; Silva, A. S. (2012) Microstructural characterization of consolidant products for historical renders: an innovative nanostructured lime dispersion and a more traditional ethyl silicate limewater solution. Microsc. Microanal., 18 [5], 1181-1189. http:// dx.doi.org/10.1017/S1431927612001341.

35. Tucker, M.E.; Wright, V.P. Carbonate. (1991) Carbonate Sedimentology, Editorial Wiley-Blackwell.

36. Deng, M.; Mingshu, T. (1993) Measures to inhibit alkalidolomite reaction. Cement Concrete Res., 23 [5], 1115-1120. http://dx.doi.org/10.1016/0008-8846(93)90171-5.

37. Ayora, C.; Taberner, C.; Saaltink, M.W.; Carrera, J. (1998) The genesis of dedolomites: A discussion based on reactive transport modeling. J. Hydrol., [209], 346-365. http:// dx.doi.org/10.1016/S0022-1694(98)00095-X.

38. García, E.; Alfonso, P.; Tauler, E.; Galí, S. (2003) Surface alteration of dolomite in dedolomitization reaction in alkaline media. Cement Concrete Res., 33 [9], 1449-1456. http:// dx.doi.org/10.1016/S0008-8846(03)00096-6.

39. Bérubé, M-A.; Choquette, M.; Locat, J. (1990) Effects of lime on common soil and rock forming minerals. Appl. Clay Sci., [5], 145-163. http://dx.doi.org/10.1016/ 0169-1317(90)90020-P

40. Chelazzi, D.; Poggi, G.; Jaidar, Y. (2013) Hydroxide nanoparticles for cultural heritage: consolidation and protection of wall paintings and carbonate materials. J. Colloid Interface Sci., [392], 42-49. http://dx.doi.org/10.1016/j. jcis.2012.09.069

41. Karatasios, I.; Kilikoglou, V.; Colston, B.; Theoulakis, P.; Watt, D. (2007) Setting process of lime-based conservation mortars with barium hydroxide. Cement Concrete Res., 37 [6], 886-893. http://dx.doi.org/10.1016/j. cemconres.2007.03.007.

42. Delgado Rodrigues, J.; Ferreira Pinto, A.P. (2016) Laboratory and onsite study of barium hydroxide as a consolidant for high porosity limestones. J. Cult. Herit., [19], 467-476. http://dx.doi.org/10.1016/j.culher.2015.10.002.

43. Terada, J. (1953) Rhombohedral Crystals of Ba-Ca and Sr-Ca Double Carbonates. J. Phys. Soc. Jpn., [7], 432-434. http://dx.doi.org/10.1143/JPSJ.7.432

44. Ferreira Pinto, A.P.; Delgado-Rodrigues, J. (2008) Stone consolidation: The role of treatment procedures. J. Cult. Herit., 9 [1], 38-53. http://dx.doi.org/10.1016/j.culher. 2007.06.004.

45. Lewin, S.Z.; Baer, N.S. (1974) Rationale of Barium Hydroxide-Urea Treatment of Decayed Stone. Stud. Conserv., 19, [1], 24-35. http://dx.doi.org/10.1179/sic.1974.002

46. Schnabel, L. (1992) Evaluation of the barium hydroxideurea consolidation, in: J.D. Rodrigues, F. Henriques, F.T. Jeremias (Eds.), Proc. $7^{\text {th }}$ Int. Cong. Deterioration and Conservation of Stone, Laboratório Nacional de Engenharia Civil (Publs.), Lisbon, 1063-1072.

47. Giorgi, R.; Ambrosi, M.; Toccafondi, N.; Baglioni, P. (2010) Nanoparticles for Cultural Heritage Conservation: Calcium and Barium Hydroxide Nanoparticles for Wall Painting Consolidation. Chemistry A European Journal, 16, [31], 9374-9382. http://dx.doi.org/10.1002/chem.201001443.

48. Baglioni, P.; Chelazzi, D.; Giorgi, R. (2015) Nanotechnologies in the conservation of cultural heritage. A compendium of materials and techniques. Edit. Springer. ISBN 978-94-017-9303-2

49. Baglioni, P.; Giorgi, R. (2006) Soft and hard nanomaterials for restoration and conservation of cultural heritage. Soft Matter., [2], 293-303. http://dx.doi.org/10.1039/ B516442G.

50. Karatasios, I.; Kilikoglou, V.; Theoulakis, P.; Colston, B.; Watt, D. (2008) Sulphate resistance of lime-based barium mortars. Cement Concrete Comp., 30 [9], 815-821. http:// dx.doi.org/10.1016/j.cemconcomp.2008.06.010.

51. Yang, K.-H; Sim, J.-I.; Nam, S.-H. (2010) Enhancement of reactivity of calcium hydroxide-activated slag mortars by the addition of barium hydroxide. Constr. Build. Mater., 24 [3], 241-251. http://dx.doi.org/10.1016/j.conbuildmat. 2009.09 .001

52. Slíížková, Z.; Drdácký, M.; Viani, A. (2015) Consolidation of weak lime mortars by means of saturated solution of calcium hydroxide or barium hydroxide. J. Cult. Herit., 16, [4], 452-460. http://dx.doi.org/10.1016/j.culher.2014.09.003.

53. Licchelli, M.; Malagodi, M.; Weththimuni, M.; Zanchi, C. (2014) Nanoparticles for conservation of bio-calcarenite stone. Appl. Phys. A. Mater. Sci. Process., [114], 673-683. http://dx.doi.org/10.1007/s00339-013-7973-z.

54. Falchi, L.; Balliana, E.; Izzo, F.C.; Agostinetto, L.; Zendri, E. (2013) Distribution of nanosilica dispersions in Lecce stone. Sciences at Ca'Foscari, [1], 40-46.

55. Okubo, T.; Nakagawa, N.; Tsuchida, A. (2007) Drying dissipative patterns of colloidal crystals of silica spheres in organic solvents. Colloid Polym. Sci., [285], 1247-1255. http://dx.doi.org/10.1007/s00396-007-1678-9.

56. Okubo, T.; Kimura, K.; Tsuchida, A. (2008) Drying dissipative patterns of colloidal crystals of silica spheres on a cover glass at the regulated temperature and humidity. Colloid Polym. Sci., [286], 621-629. http://dx.doi. org/10.1007/s00396-007-1808-4.

57. Zornoza-Indart, A.; López-Arce, P. (2016) Silica nanoparticles $\left(\mathrm{SiO}_{2}\right)$ : Influence of relative humidity in stone consolidation. J. Cult. Herit., [18], 258-270. http://dx.doi. org/10.1016/j.culher.2015.06.002.

58. Ruffolo, S.A.; La Russa, M.F; Ricca, M; Belfiore, C.M. Macchia, A.; Comite, V.; Pezzino, A.; Crisci, G.M. (2015) New insights on the consolidation of salt weathered limestone: the case study of Modica stone. Bull. Eng. Geol. Env., 1-10. http://dx.doi.org/10.1007/s10064-015-0782-1.

59. Zendri, E.; Biscontin, G.; Nardini, I.; Rialto, S. (2007) Characterization and reactivity of silicatic consolidants. Constr. Buildi. Mater., [21], 1098-1106. http://dx.doi. org/10.1016/j.conbuildmat.2006.01.006.

60. Aggarwal, P.; Pratap Singh, R.; Aggarwal, Y. (2015) Use of nano-silica in cement based materials-A review. Cogent Engineering, [2], 1078018. http://dx.doi.org/10.1080/233119 16.2015.1078018.

61. Sáez del Bosque, I.F.; Martínez-Ramírez, S.; BlancoVarela, M.T. (2015) Calorimetric study of the early stages of the nanosilica-tricalcium silicate hydration. Effect of temperature. Mater. Construc., 65 [320], e070. http://dx.doi. org/10.3989/mc.2015.06814.

62. Favaro, M.; Tomasin, P.; Ossola, F.; Vigato, P.A. (2008) A novel approach to consolidation of historical limestone: the calcium alkoxides. Appl. Organomet. Chem., 22 [12], 698-704. http://dx.doi.org/10.1002/aoc.1462.

63. Natali, I.; Tomasin, P.; Becherini, F.; Bernardi, A.; Ciantelli, C.; Favaro, M.; Favoni, O.; Forrat Pérez, V.J.; Olteanu, I.D.; Romero Sánchez, M.D.; Vivarelli, A.; Bonazza, A. (2015) Innovative consolidation products for Stone materials: field exposure tests as a valid approach for assessing durability. Heritage Science, 3 [6]. http://dx.doi.org/10.1186/ s40494-015-0036-3.

64. Ossola, F.; Tomasin, P.; De Zorzi, C.; El Habra, N.; Chiurato, M.; Favaro, M. (2012) New calcium alkoxides for consolidation of carbonate rocks. Influence of precursors characteristics on morphology, crystalline phase and consolidation effects. New J. Chem., [36], 2618-2624. http:// dx.doi.org/10.1039/C2NJ40708F.

65. Favaro, M.; Chiurato, M.; Tomasin, P.; Ossola, F.; El Habra, N.; Brianese, N.; Svensson, I.; Beckers, E.; Forrat Pérez, V.; Romero Sánchez, M.D.; Bernirdi, A. (2014) Calcium and Magnesium Alkoxides for Conservation Treatment of Stone and Wood in Built Heritage. In Built Heritage: Monitoring Conservation Management, L. Toniolo, M. Boriani and G. Guidi Editors Book, Springer Berlin, 413-422. http://dx.doi. org/10.1007/978-3-319-08533-3_35.

66. Sassoni, E; Naidu, S. Scherer, G.W. (2011) The use of hydroxiapatite as a new inorganic consolidant for damaged carbonate stones. J. Cult. Herit., [12], 346-355. http:// dx.doi.org/10.1016/j.culher.2011.02.005

67. Sassoni, E.; Franzoni, E. (2014) Sugaring marble in the Monumental Cemetery in Bologna (Italy): characterization of naturally and artificially weathered samples and first results of consolidation by hydroxiapatite. Appl. Phys. A., 117 [4], 1893-1906. http://dx.doi.org/10.1007/ s00339-014-8629-3. 
68. Sassoni, E.; Franzoni, E.; Pigino, B.; Scherer, G.W.; Naidu, S. (2013) Consolidation of calcareous and siliceous sandstones by hydroxiapatite: comparison with TEOS-based consolidant. J. Cult. Herit., [14], 103-108. http://dx.doi. org/10.1016/j.culher.2012.11.029.

69. Yang, F-W.; Liu, Y.; Zhu Y.; Long, S.; Zuo, G-F.; Wang, C-Q.; Guo, F.; Zhang, B-J.; Jiang, S-W. (2012) Conservation of weathered historic sandstone with biomimetic apatite. Chin. Sci. Bull., [57], 2171-2176. http://dx.doi.org/10.1007/ s11434-012-5039-9.

70. Naidu, S.; Scherer, G.W. (2014) Nucleation, growth and evolution of calcium phosphate films on calcite. J. Colloid Interface Sci., [435], 128-137. http://dx.doi.org/10.1016/j. jcis.2014.08.018.

71. Naidu, S.; Sassoni, E.; Scherer, G.W. (2011) New treatment for Corrosion-Resistant Coatings for Marble and Consolidation of Limestone, in Stefanaggi M., VergèsBelmin V. (Eds), Jardins de Pierres - Conservation of stone in Parks, Gardens and Cemeteries, Paris, 22-24 June 2011, p. 289-294. ISBN: 2-905430-17-6

72. Franzoni, E.; Sassoni, E.; Graziani, G. (2015) Brushing, poultice or immersion? Role of the application technique on the performance of a novel hydroxiapatite-based consolidating treatment for limestone, J. Cult. Herit., [16], 173-184. http://dx.doi.org/10.1016/j.culher.2014.05.009.

73. Sassoni, E.; Graziani, G.; Franzoni, E. (2016) An innovative phosphate-based consolidant for limestone. Part 1: Effectiveness and compatibility in comparison with ethyl silicate. Constr. Build. Mater., [102], 918-930. http:// dx.doi.org/10.1016/j.conbuildmat.2015.04.026.

74. Sassoni, E.; Graziani, G.; Franzoni, E. (2016) An innovative phosphate-based consolidant for limestone. Part 2: Durability in comparison with ethyl silicate. Constr Build. Mater., [102], 931-942. http://dx.doi.org/10.1016/j. conbuildmat.2015.10.202.

75. Ion, R-M.; Turcanu-Carutiu, D.; Fierascu, R-C.; Fierascu, I. (2014) Chalk Stone restoration with hydroxiapatite-based nanoparticles. SBMM, [12], 9: 24

76. Ion, R-M.; Turcanu-Carutiu, D.; Fierascu, R-C.; Fierascu, I.; Bunghez, I-R.; Ion, M-L.; Teodorescu, S.; Vasilievici, G.; Raditoiu, V. (2015) Caoxite-hydroxyapatite composition as consolidating material for the chalk stone from Basarabi-Murfatlar chuches ensemble. Appl. Surf. Sci., [358], 612-618. http://dx.doi.org/10.1016/j. apsusc.2015.08.196.

77. Wheeler, G. (2005) Alkoxysilanes and the consolidation of stone. Getty Publications, LA, California, US.

78. Illescas, J.F.; Mosquera, M. (2011) Surfactant-Synthesized PDMS/Silica Nanomaterials Improve Robutness and Stain Resistance of Carbonate Stone. J. Phys. Chem. C. 115, [30], 14624-14634. http://dx.doi.org/10.1021/jp203524p.

79. Mosquera, M.J.; de los Santos, D.M.; Rivas, T. (2010) Surfactant-Synthesized Ormosils with Application to Stone Restoration. Langmuir, [26], 6737-6745. http:// dx.doi.org/10.1021/la9040979.

80. Mosquera, M.J.; de los Santos, D.M.; Valdéz-Castro, L.; Esquivias, L. (2008) New route for producing crackFree xerogels: obtaining uniform pore size, J. Non-Cryst. Solids., [354], 645-650. http://dx.doi.org/10.1016/j. jnoncrysol.2007.07.095.

81. De Rosario Amado, I.; Elhaddad, F.; Pan Cabo, A.; Mosquera, M.J. (2015) Effectiveness of a novel consolidant on granite: Laboratory and in situ results, Constr. Build. Mater., [76], 140-149. http://dx.doi.org/10.1016/j. conbuildmat.2014.11.055.

82. Simionescu, B.; Olaru, M.; Aflori, M. (2010) Silsesquioxane-based Hybrid Nanocomposite with Self-assembling Properties for Porous Limestones Conservation. High Perform. Polym., [22], 42-55. http:// dx.doi.org/10.1177/0954008308100905.

83. Zornoza-Indart, A.; López-Arce, P.; Leal, N.; Simao, J.; Zoghlami, K. (2016) Consolidation of a Tunisian bioclastic calcarenite: From conventional ethyl silicate products to nanostructured and nanoparticle based consolidants. Constr. Build. Mater., 116 [30], 188-202. http://dx.doi. org/10.1016/j.conbuildmat.2016.04.114.
84. Scherer, G.W. (1990) Theory of Drying. J. Am. Ceram. Soc., 73 [1], 3-14. http://dx.doi.org/10.1111/j.1151-2916.1990. tb05082.x.

85. Miliani, C.; Velo-Simpson, M.L.; Scherer, G.W. (2007) Particle-modified consolidants: A study on the effect of particles on sol-gel properties and consolidation effectiveness. J. Cult. Herit., [8], 1-6. http://dx.doi.org/10.1016/j. culher.2006.10.002.

86. Escalante, M.R.; Valenza, J.; Scherer, G.W. (2000) Proceedings of the $9^{\text {th }}$ International Congress on Deterioration and Conservation of Stone, Venice, 19-24 June, 2000, Fassina, V. (ed.) New York, Elsevier.

87. Aggelakopoulou, E.; Charles, P.; Acerra, M.E.; García, A.I.; Flatt, R.J.; Scherer, G.W. (2002) Rheology Optimization of Particle Modified Consolidants. MRS Proceedings, 712: II2.6. http://dx.doi.org/10.1557/PROC-712-II2.6.

88. Verganelaki, A.; Kilikoglou, V.; Karatasios, I.; MaravelakiKalaitzaki, P. (2014) A biomimetic approach to strengthen and protect construction materials with a novel calciumoxalate-silica nanocomposite. Constr. Build. Mater., [62], 8-17. http://dx.doi.org/10.1016/j.conbuildmat.2014.01.079.

89. Vázquez-Calvo, C.; Ávarez de Buergo, M.; Fort, R.; VarasMuriel, M.J. (2007) Characterization of patinas by means of microscopic techniques. Mater. Charact., [58], 11-12: 1119-1132. http://dx.doi.org/10.1016/j.matchar.2007.04.024.

90. Verganelaki, A.; Kapridaki, C.; Maravelaki-Kalaitzaki, P. (2015) Modified tetraethoxysilane with nano-calcium oxalate in one-pot synthesis for protection of building materials. Ind. Eng. Chem. Res., [54], 7195-7206. http:// dx.doi.org/10.1021/acs.iecr.5b00247.

91. Tuteja, A.; Choi, W.; Ma, M.; Mabry, J.M.; Mazzella S.A; Rutledge, G.C.; McKinley, G.H.; Cohen, R.E. (2007) Designing superoleophobic surfaces. Science, [318], 1618. http://dx.doi.org/10.1126/science.1148326.

92. Manoudis, P.N.; Karapanagiotis, I.; Tsakalof, A.; Zuburtikudis, I.; Panayiotou, C. (2009) Superhydrophobic composite films produced on various substrates. Langmuir, [24], 11225-11232. http://dx.doi.org/10.1021/la801817e.

93. Manoudis, P.N.; Karapanagiotis, I.; Tsakalof, A.; Zuburtikudis, I.; Kolinkeová, B.; Panayiotou, C. Superhydrophobic films for the protection of outdoor cultural heritage assets Appl. Phys. A, [97], 351-360. http:// dx.doi.org/10.1007/s00339-009-5233-z.

94. Chao-Hua,X.; Shun-Tian, J.;Jing,Z.; Jian-Zhong, M.(2010) Large-area fabrication of superhydrophobic surfaces for practical applications: an overview. Sci. Tech. Adv. Mater., 11, [3], http://dx.doi.org/10.1088/1468-6996/11/3/033002.

95. De Ferri L., Lottici P.P., Lorenzi, A. Montenero A., Salvioli-Mariani E., (2011) Study of silica nanoparticles polysiloxane hydrophobic treatments for stone-based monument protection. J. Cult. Herit., 12, [4], 356-363. http:// dx.doi.org/10.1016/j.culher.2011.02.006.

96. La Russa, M.F.; Ruffolo, S.A.; Rovella, N.; Belfiore, C.M.; Palermo, A.M.; Guzzi, M.T.; Crisci, G.M. (2012) Multifunctional $\mathrm{TiO}_{2}$ coatings for Cultural Heritage. Prog. Org. Coat., [74], 186-191. http://dx.doi.org/10.1016/j. porgcoat.2011.12.008.

97. Kapridaki, C.; Maravelaki-Kalaitzaki, P. (2013) $\mathrm{TiO}_{2-}$ $\mathrm{SiO}_{2}$-PDMS nano-composite hydrophobic coating with self-cleaning properties for marble protection. Prog. Org. Coat., 76 [2-3], 400-410. http://dx.doi.org/10.1016/j. porgcoat.2012.10.006.

98. Cappelletti, G.; Fermo, P.; Camiloni, M. (2015) Smart hybrid coatings for natural stones conservation. Prog. Org. Coat., s, [78], 511-516. http://dx.doi.org/10.1016/j. porgcoat.2014.05.029.

99. Söz, C.K., Yilgör, E., Yilgör, I. (2015) Influence of the coating method on the formation of superhydrophobic silicone-urea surfaces modified with fumed silica nanoparticles. Prog. Org. Coat., [84], 143-152. http://dx.doi. org/10.1016/j.porgcoat.2015.03.015.

100. Sun, M.; Luo, C.; Xu, L.; Ji, H.; Ouyang, Q.; Yu, D.; Chen, Y. (2005) Artificial lotus leaf by nanocasting, Langmuir, [21], 8978-8981. http://dx.doi.org/10.1021/la050316q.

101. Krumpfer, W.; McCarthy, T.J. (2010) Contact angle hysteresis: a different view and a trivial recipe for low 
hysteresis hydrophobic surfaces, Farad. Discuss., [146], 103-111. http://dx.doi.org/10.1039/B925045J.

102. Chen, W.; Fadeev, A.Y.; Hsieh, M.C.; Oner, D.; Youngblood, J.; McCarthy, T.J. (1999) Ultrahydrophobic and ultralyophobic surfaces: Some comments and examples Langmuir, 15 [10], 3395-3399. http://dx.doi.org/10.1021/la990074s.

103. Jung, C.; Bhushan, B. (2006) Contact angle, adhesion and friction properties of micro-and nanopatterned polymers for superhydrophobicity, Nanotechnology, 17 [19], 4970-4980. http://dx.doi.org/10.1088/0957-4484/17/19/033.

104. Manoudis, P.N.; Karapanagiotis, I. (2014) Modification of the wettability of polymer surfaces using nanoparticles, Prog. Org. Coat., [77], 331-338. http://dx.doi.org/10.1016/j. porgcoat.2013.10.007.

105. Oner, D. T.; McCarthy, J. (2000) Ultrahydrophobic surfaces. Effects of topography lengthscales on wettability, Langmuir, 16 [20], 294. http://dx.doi.org/10.1021/ la000598o.

106. Takeshita, N.; Paradis, L.A.; Oner, D.; McCarthy, T.J.; Chen, W. (2004) Simultaneous tailoring of surface topography and chemical structure for controlled wettability. Langmuir, 20 [19], 8131-8136. http://dx.doi.org/10.1021/ la 0494041

107. Cassie, A.B.D.; Baxter, S. (1944), Wettability of porous surfaces, T. Faraday Soc., 40546-551. http://dx.doi. org/10.1039/TF9444000546.

108. Söz, C.K.; Yilgör, E.; Yilgör, I.; (2015) Influence of the average surface roughness on the formation of superhydrophobic polymer surfaces through spin-coating with hydrophobic fumed silica. Polymer, [62], 118-128. http://dx.doi. org/10.1016/j.polymer.2015.02.032.

109. Domingo, C.; Álvarez de Buergo, M.; Sánchez-Cortés, S.; Fort, R.; García-Ramos, J.V. Possibilities of the molecular Infrared and Raman spectroscopies to monitor the polymerization process of water repellents and consolidants in stones. Prog. Org. Coat., 63 [1], 5-12. http://dx.doi. org/10.1016/j.porgcoat.2008.03.002.

110. Lampakis, D.; Manoudis, P.N.; Karapanagiotis, I. (2013) Monitoring the polymerization process of Si-based superhydrophobic coatings using Raman spectroscopy. Prog. Org. Coat., [76], 488-494. http://dx.doi.org/10.1016/j. porgcoat.2012.11.002.

111. Illescas, J.F.; Mosquera, M.J. (2012) Producing SurfactantSynthesized Nanomaterials In Situ on a Building Substrate, without Volatile Organic Compounds. ACS Appl. Mater. Inter., [4], 4259-4269. http://dx.doi.org/10.1021/ am300964q

112. Sparks, B.J.; Hoff, E.F.T.; Xiong, L.; Goetz, J.T.; Patton, D.L. (2013) Superhydrophobic Hybrid-Inorganic-Organic Thiol-ene Surfaces Fabricated via Spray-Deposition and Photopolymerization. ACS Appl. Mater. Inter., [5], 18111817. http://dx.doi.org/10.1021/am303165e

113. Xiong, L.; Kendrick, L.L.; Heusser, H.; Webb, J.C.; Sparks, B.J.; Goetz, J.T.; Guo, W.; Stafford, C.M.; Blanton, M.D.; Nazarenko, S.; Patton, D.L. (2014) Spray-Deposition and Photopolimerization of Organic-Inorganic Thiol-ene Resins for Fabrication of Superamphiphobic Surfaces. ACS Appl. Mater. Inter., [9], 10763-74. http://dx.doi. org/10.1021/am502691g.

114. Pedna, A.; Pinho, L.; Frediani, P.; Mosquera, M.J. (2016) Obtaining $\mathrm{SiO}_{2}$-fluorinated PLA bionanocomposites with application as reversible and higly-hydrophobic coatings of buildings. Prog. Org. Coat., [90], 91-100. http://dx.doi. org/10.1016/j.porgcoat.2015.09.024.

115. Álvarez de Buergo, M.; Fort, R. (2001) A basic methodology for evaluating and selecting water-proofing treatments apllied to carbonatic materials. Prog. Org. Coat., [43], 258-266

116. Verho, T.; Bower, C.; Andrew, P.; Franssila, S.; Ikkala, O.; Ras, R.H.A. (2011) Mechanically durable superhydrophobic surfaces, Adv. Mater, 23 [5], 673-678. http://dx.doi. org/10.1002/adma.201003129.

117. Beydoun, D.; Amal, D.; Lowand, G.; McEvoy, S. (1999) Role of nanoparticles in photocatalysis. J. Nanopart. Res., [1], 439-458. http://dx.doi.org/10.1023/A:101004 4830871 .
118. Bahnemann, D. (2004). Photocatalytic water treatment: Solar energy applications. Sol. Ener., [77], 445-459. http:// dx.doi.org/10.1016/j.solener.2004.03.031.

119. Fujishima, A.; Rao, T.N.; Tryk, D.A. (2000) Titanium dioxide photocatalysis, J. Photoch. Photobio C, [1], 1-21. http://dx.doi.org/10.1016/S1389-5567(00)00002-2.

120. Schodek, D. L.; Ferreira, P.; Ashby, M. F. (2009) Nanomaterials, nanotechnologies and design: an introduction for engineers and architects. Butterworth-Heinemann. ISBN: 978-0-7506-8149-0

121. Wang Y.; Herron, N. (1991) Nanometer-sized semiconductor clusters: Materials synthesis, quantum size effects, and photophysical properties. J. Phys. Chem., [95], 525-532. http://dx.doi.org/10.1021/j100155a009.

122. Beydoun, d.; Amal, R.; Lowand, G.; McEvoy, S. (1999) Role of nanoparticles in photocatalysis, J. Nanopart. Res., [1], 439-458. http://dx.doi.org/10.1023/A:1010044830871.

123. Bengtsson, N.; Castellote, M. (2014) Heterogeneous photocatalysis on construction materials: effect of catalyst properties on the efficiency for degrading NOx and self cleaning, Mater. Construcc., 64 [314], e013 http://dx.doi. org/10.3989/mc.2014.06713.

124. Munafò, P.; Goffredo, G. B.; Quagliarini, E. (2015) $\mathrm{TiO}_{2-}$ based nanocoatings for preserving architectural stone surfaces: An overview. Constr. Build. Mater, [84], 201-218, http://dx.doi.org/10.1016/j.conbuildmat.2015.02.083.

125. Colangiuli, D.; Calia, A.; Bianco, N. (2015) Novel multifunctional coatings with photocatalytic and hydrophobic properties for the preservation of the stone building heritage. Constr. Build. Mater., [93], 189-196. http://dx.doi. org/10.1016/j.conbuildmat.2015.05.100.

126. Guan, K. (2005) Relationship between photocatalytic activity, hydrophilicity and self-cleaning effect of $\mathrm{TiO}_{2} / \mathrm{SiO}_{2}$ films. Surf. Coat. Tech., 191 [2], 155-160. http://dx.doi. org/10.1016/j.surfcoat.2004.02.022.

127. Calia, A.; Matera, L.; Lettieri, M.T. (2012) Compact limestones as historical building material: properties of the Trani stone (Apulia, southern Italy) and preliminary study for self cleaning treatments, 12th International Congress on the Deterioration and Conservation of Stone Columbia University, New York.

128. Goffredo, G.B.; Quagliarini, E.; Bondioli, F.; Munafo, E. (2014) $\mathrm{TiO}_{2}$ nanocoatings for architectural heritage: Self-cleaning treatments on historical stone surfaces. Proceedings of the Institution of Mechanical Engineers, Part N: Journal of Nanoengineering and Nanosystems., http://dx.doi.org/10.1177/1740349913506421.

129. Licciulli, A.; Calia A.; Lettieri, M.; Diso, D.; Masieri, M.; Franza, S. (2011) Photocatalytic $\mathrm{TiO}_{2}$ coatings on limestone. J. Sol-Gel Sci. Technol.; [60], 437-44. http://dx.doi. org/10.1007/s10971-011-2574-9.

130. Pinho, L.; Elhaddad, F.; Facio, D. S.; Mosquera, M. J. (2013) A novel $\mathrm{TiO}_{2}-\mathrm{SiO}_{2}$ nanocomposite converts a very friable stone into a self-cleaning building material. Appl. Surf. Sci., [275], 389-396. http://dx.doi.org/10.1016/j. apsusc. 2012.10.142.

131. Bergamonti, L.; Alfieri, I.; Lorenzi, A.; Montenero, A.; Predieri, G.; Barone, G.; Lottici, P. P. (2013) Nanocrystalline $\mathrm{TiO}_{2}$ by sol-gel: Characterisation and photocatalytic activity on Modica and Comiso stones. Appl. Surf. Sci., [282], 165-173. http://dx.doi.org/10.1016/j. apsusc.2013.05.095.

132. Luvidi, L.; Laguzzi, G.; Gallese, F.; Mecchi, A.M.; Sidoti, G. (2010) Application of $\mathrm{TiO}_{2}$ based coatings on stone surfaces of interest in the field of cultural heritage. In: Ferrari A, editor. 4th International Congress on Science and technology for the safeguard of Cultural heritage in the Mediterranean Basin, vol. 2. Napoli: Grafica Elettronica; p. $495-500$.

133. Munafò, P.; Quagliarini, E.; Goffredo, G. B.; Bondioli, F.; Licciulli, A. (2014) Durability of nano engineered $\mathrm{TiO}_{2}$ self-cleaning treatments on limestone. Constr. Build. Mater., [65], 218-231. http://dx.doi.org/10.1016/j. conbuildmat.2014.04.112.

134. Pinho, L.; Mosquera, M. J. (2011) Titania-silica nanocomposite photocatalysts with application in stone 
self-cleaning. J. Phys. Chem. C, 115 [46], 22851-22862. http://dx.doi.org/10.1021/jp2074623.

135. Graziani, L.; Quagliarini, E.; Bondioli, F.; D’Orazio, M. (2014) Durability of self-cleaning $\mathrm{TiO}_{2}$ coatings on fired clay brick façades: Effects of UV exposure and wet \& dry cycles. Build. Environ., [71], 193-203. http://dx.doi. org/10.1016/j.buildenv.2013.10.005.

136. Diamanti, M. V.; Ormellese, M.; Pedeferri, M. (2008) Characterization of photocatalytic and superhydrophilic properties of mortars containing titanium dioxide. Cement Concrete Res., 38, [11], 1349-1353. http://dx.doi. org/10.1016/j.cemconres.2008.07.003.

137. Lucas, S. S., Ferreira, V. M.; Barroso de Aguiar, J.L. (2013) Incorporation of titanium dioxide nanoparticles in mortars-Influence of microstructure in the hardened state properties and photocatalytic activity. Cement Concrete Res., [43], 112-120. http://dx.doi.org/10.1016/j. cemconres.2012.09.007.

138. La Russa, M.F; Macchia, A.; Ruffolo, S.A.; De Leo, F; Barberio, M.; Barone, P.; Crisci, G.M.; Urzi, C. (2014) Testing the antibacterial activity of doped $\mathrm{TiO}_{2}$ for preventing biodeterioration of cultural heritage building materials. Int. Biodeter. Biodegr., [96], 87-96. http://dx.doi. org/10.1016/j.ibiod.2014.10.002.

139. Quaresima, R.; Baccante, A.; Volpe, R.; Corain, B. (1997) Realization and Possibility of Polymeric Mataloorganic Matrixes with Biocides Activity. In New Concepts, Technologies and Materials for the Conservation and Management of Historic Cities, Sites and Complexes, Volume 3, ed. A. Moropoulou, F. Zezza, E. Kollias, and I. Papachristodoulou, pp. 323-335. Athens.

140. Pinna, D.; Salvadori, B.; Galeotti, M. (2012) Monitoring the performance of innovative and traditional biocides mixed with consolidants and water-repellents for the prevention of biological growth on stone. Sci. Total Environ., [15], 132-141. http://dx.doi.org/10.1016/j. scitotenv.2012.02.012.

141. Ditaranto, N.; Loperfido, S.; Van der Werf, I.; Mangone, A.; Cioffi, N.; Sabbatini, L. (2011) Synthesis and analytical characterisation of copper-based nanocoatings for bioactive stone artworks treatment. Anal. Bioanal. Chem., [399], 473-481. http://dx.doi.org/10.1007/s00216-010-4301-8.

142. Pinna, D.; Salvadori, B.; Galeotti, M. (2012) Monitoring the performance of innovative and traditional biocides mixed with consolidants and water-repellents for the prevention of biological growth on stone. Sci. Total Environ., [423], 132-141. http://dx.doi.org/10.1016/j. scitotenv.2012.02.012

143. Bellissima, F.; Bonini, M.; Giorgi, R.; Baglioni, P.; Barresi, P.; Mastromei, G.; Perito, B. (2014) Antibacterial activity of silver nanoparticles grafted on stone surface. Environ. Sci. Pollut. R., [21], 13278-13286. http://dx.doi. org/10.1007/s11356-013-2215-7.

144. Aflori, M.; Simionescu, B.; Bordiani, I.; Olaru, M. (2013) Silesquioxane-based hybrid nanocomposite with methacrylate units containing titania and/or silver nanoparticles as antibacterial/antifungal coatings for monumental stones. Mat. Sci. Eng. B., 178 [19], 1339-1346. http://dx.doi.org/10.1016/j.mseb.2013.04.004.

145. Carrillo-González, R.; Martínez-Gómez, M.A.; GonzálezChávez, M.D.; Mendoza Hernández, J.C. (2016) Inhibition of microorganisms involved in deterioration of an archaeological site by silver nanoparticles produced by a green synthesis method. Sci. Total Environ., [16], 30320-30325. http://dx.doi.org/10.1016/j.scitotenv.2016.02.110

146. Janaki, A.C.; Sailatha, E.; Gunasekaran, S. (2015) Synthesis, characteristics and antimicrobial activity of $\mathrm{ZnO}$ nanoparticles. Spectrochim. Acta Mol. Biomol. Spectrosc., [144], 17-22. http://dx.doi.org/10.1016/j.saa.2015.02.041.

147. Van der Weerf, I.D.; Ditaranto, N.; Picca, R.A.; Sportelli, M.C.; Sabbatini, L. (2015) Development of a novel conservation treatment of stone monuments with bioactive nanocomposites. Heritage Science, 3, [29]. http://dx.doi. org/10.1186/s40494-015-0060-3.

148. Ditaranto, N.; Van der Werf, I.D.; Picca, R.A.; Sportelli, M.C.; Giannossa, L.C.; Bonerba, E.; Tantillo, G.; Sabbatini, L. (2015) Characterization and behaviour of $\mathrm{ZnO}$-based nanocomposites designed for the control of biodeterioration of patrimonial stoneworks. New J. Chem., [39], 6836-6843. http://dx.doi.org/10.1039/ C5NJ00527B.

149. Gómez-Ortíz, N.; De la Rosa-García, S.; González-Gómez, W.; Soria-Castro, M.; Quintana, P.; Oskam, G.; OrtegaMorales, B. (2013) Antifungal coatings base don $\mathrm{Ca}(\mathrm{OH})_{2}$ mixed with $\mathrm{ZnO}-\mathrm{TiO}_{2}$ nanomaterials for protection of limestone monuments. ACS Appl. Mater. Interfaces., 13 [5], 1556-1565. http://dx.doi.org/10.1021/am302783h.

150. Gómez-Ortiz, N.M ; González-Gómez, W.S : De la RosaGarcía, S.C.; Oskam, G.; Quintana, P.; Soria-Castro, M.; Gómez-Cornelio, S.; Ortega-Morales, B.O. (2014) Antifungal activity of $\mathrm{Ca}\left[\mathrm{Zn}(\mathrm{OH})_{3}\right]_{2} \cdot 2 \mathrm{H}_{2} \mathrm{O}$ coatings preservation of limestone monuments: An in vitro study. Int. Biodeterior. Biodegradation., [91], 1-8. http://dx.doi. org/10.1016/j.ibiod.2014.02.005.

151. Ruffolo, S.A. La Russa, M.F. Malagodi, M. Oliviero, Rossi, C.; Palermo, A.M.; Crisci, G.M. (2010) ZnO and $\mathrm{ZnTiO}_{3}$ nanopowders for antimicrobial stone coating. Appl. Phys. A: Mater. [100], 829-834. http://dx.doi. org/10.1007/s00339-010-5658-4.

152. Ruffolo, S.A.; Macchia, A.; La Russa, M.F.; Mazza, L.; Urzi, C.; De Leo, F.; Barberio, M.; Crisci, G.M. (2013) Marine antifouling for underwater archaeological sites: $\mathrm{TiO}_{2}$ and Ag-Doped $\mathrm{TiO}_{2}$. Int. J. Photoenergy, ID 251647 , 6p. http://dx.doi.org/10.1155/2013/251647.

153. La Russa, M.F. Macchia, A ; Ruffolo, S.A. De Leo, F; Barberio, M.; Barone, P.; Crisci, G.M.; Urzi, C. (2014) Testing the antibacterial activity of doped $\mathrm{TiO}_{2}$ for preventing biodeterioration of cultural heritage building materials. Int. Biodeter. Biodegr., [96], 87-96. http://dx.doi. org/10.1016/j.ibiod.2014.10.002. 